\title{
Occurrence of fossil organic matter in modern environments: Optical, geochemical and isotopic evidence
}

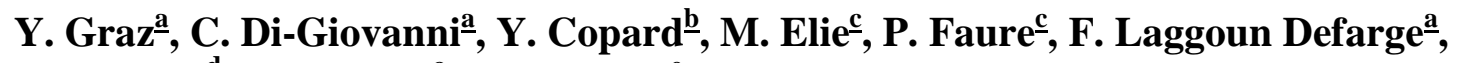 \\ J. Lévèque ${ }^{\mathrm{d}}$, R. Michels ${ }^{\mathrm{c}}$, J.E. Olivier ${ }^{\mathrm{e}}$
}

a ISTO, Université d'Orléans/Université François Rabelais de Tours, CNRS/INSU UMR 6113, 1A rue de la Férollerie, 45072 Orléans, France

b M2C, UMR 6143 CNRS/Université de Rouen, place E. Blondel, Bat. Irese A, Université de Rouen, 76821 Mont Saint Aignan Cedex, France

c G2R UMR 7566 CNRS/Université Henri Poincaré, BP 239, 54506 Vandœuvre-lès-Nancy Cedex, France

${ }^{\mathrm{d}}$ UMR A111 INRA/Université de Bourgogne - GéoSol, 6 bd Gabriel, 21000 Dijon, France

e CEMAGREF, Grenoble, Unité de recherche ETNA, BP 76, 38402 Saint Martin d'Hères, France

\begin{abstract}
This study relates to the input and fate of fossil organic matter (FOM) in the modern environment, and focuses on two experimental watersheds overlying Jurassic marls: Le Laval and Le Brusquet ( $1 \mathrm{~km}^{2}$ in area), located near Digne, Alpes-de-Haute-Provence, France.

Considering that FOM delivery is mainly a result of different processes affecting sedimentary rocks [(bio)chemical and mechanical weathering], samples from different pools were collected: bedrocks, weathering profiles, soils and riverine particles. The samples were examined using complementary techniques: optical (palynofacies methods), geochemical (Rock-Eval 6 pyrolysis, C/N ratio), molecular (gas chromatography/mass spectrometry) and isotopic (stable $\mathrm{C}$ isotopic composition). As a result, FOM markers were identified and tracked through the different pools. The results highlight the contribution of FOM, which can be found in all the studied pools. Transfer of FOM between bedrocks/weathering profiles (governed mainly by chemical weathering) and bedrocks/riverine particles (governed mainly by mechanical weathering) reveals any qualitative change. Weathering profiles/soils transition [governed by (bio)chemical weathering] is characterized by alteration of the FOM, which is difficult to describe because fossil material is mixed with recent organic matter (ROM). Despite this latter point, the study provides evidence for a relative resistance of FOM to weathering processes and points to its contribution to the modern geosystem and the $\mathrm{C}$ cycle.
\end{abstract}

\section{Introduction}

The current increase in atmospheric $\mathrm{CO}_{2}$ since the industrial revolution could induce a series of climatic, environmental and human consequences which are still poorly understood, but potentially alarming (IPCC, 2007). Many studies focus on the numerous unknowns concerning the mechanisms controlling $\mathrm{C}$ fluxes which occur between different $\mathrm{C}$ pools such as atmosphere, hydrosphere, soil, biomass and lithosphere ( [Houghton, 1998] and [Houghton, 2005]).

For the 1980-1989 decade, an initial assessment shows that deforestation and fossil C burning could respectively release 1-2.7 and 5.4-6.6 Gt C/a into the atmosphere ( [Watson et al., 
1990] , [Houghton, 1991] and [Houghton, 1998] ). Considering that 1.7-2.8 Gt C/a are pumped every year by the oceans (Sarmiento and Sundquist, 1992), the increase in atmospheric $\mathrm{CO}_{2}$ has been estimated to be from 4.7 to $5.3 \mathrm{Gt} \mathrm{C} / \mathrm{a}$. However, such estimates are largely higher than current measurements, which give values that do not exceed $3.4 \mathrm{Gt} \mathrm{C} / \mathrm{a}$ ( [Watson et al., 1990] , [Schimmel, 1994], Amiotte-Suchet, 1995, [Houghton, 1998] , [Houghton, 2005] and IPCC, 2007).

Fluxes between the atmosphere, biosphere and oceans have been successively raised to explain this difference ( [Tans et al., 1990] , [Dai and Fung, 1993] , [Harrison and Broecker, 1993] , [King et al., 1995] and [Kaufmann and Stock, 2003] ), but the difference does provide evidence that many unknowns affect the proposed estimates. For example, the fate of fossil organic $\mathrm{C}$ (FOC) released by the weathering of sedimentary rocks and metamorphic rocks, which can supply soil, rivers and the atmosphere, remains poorly examined and misunderstood. Indeed, numerous estimates of soil and river $\mathrm{C}$ amounts or fluxes have been calculated ( [Holland, 1978] , [Adams et al., 1990] , [Degens et al., 1991] , Probst, 1992, [Eswaran et al., 1993], Amiotte-Suchet, 1995, [Balesdent, 1996] , [Batjes, 1996], Adams and Faure, 1996, [Ludwig et al., 1996] , [Carter et al., 1997] and [Aitkenhead and McDowell, 2000] ). All these estimates rely on the prerequisite that the organic C (OC) occurring in soil or loaded into rivers originates exclusively from present day biological production. They do not take into account numerous field studies that have shown the occurrence of FOC in modern C pools such as soil ( [Lichtfouse et al., 1997a] , [Lichtfouse et al., 1997b] , [DiGiovanni et al., 1998] , [Di-Giovanni et al., 1999] , [Di-Giovanni et al., 2000] , [Blair et al., 2003] and [Copard et al., 2006] ), rivers ( [Dow, 1977] , [Bilodeau et al., 1990] , [Di-Giovanni et al., 2000] , [Kao and Liu, 1996] , [Masiello and Druffel, 2001] , [Blair et al., 2003] , [Blair et al., 2004] , [Blair et al., 2010] , [Raymond and Bauer, 2001] , [Raymond and Bauer, 2004], [Gomez et al., 2003] , [Komada et al., 2005] , [Copard et al., 2006], [Leithold et al., 2006] and [Hilton et al., 2008] ) and recent sediments ( [Groot et al., 1967] , [Groot and Groot, 1971], Combaz et al., 1977, [Truswell and Drewry, 1984] , [Hart et al., 1994] , [Tyson, 1995] , [Di-Giovanni et al., 1997] , [Di-Giovanni et al., 1998] , [Di-Giovanni et al., 1999] , [DiGiovanni et al., 2000] , [Eglinton et al., 1997] , [Moran et al., 1998] , [Ludwig, 2001] , [Leithold and Blair, 2001] , [Blair et al., 2003] , [Blair et al., 2010] , [Wakeham et al., 2004] , [Dickens et al., 2004a] and [Dickens et al., 2004b] ), thereby revealing a strong resistance to weathering processes and its importance on a global scale.

The present study attempts to help clarify the fate of FOM (bearing FOC) released from rock weathering and proposes a first field study marked by a "multi-pool-multi-analytical" approach. Optical, isotopic chemical and molecular investigations have been conducted with the aim of estimating the FOM contribution to various continental $\mathrm{C}$ reservoirs such as weathering profiles, soil and riverine loads. This work focuses on watersheds lying on marly bedrocks as these rocks are characterized by (i) a significant amount of FOC (generally $>0.5 \%$, Ronov and Yaroshevskiy, 1976), (ii) a strong erodibility (Nadal-Romero et al., 2008) and (iii) a widespread area on continental surfaces (Amiotte-Suchet et al., 2003). In addition, the sampling sites are experimental watersheds monitored by the Cemagref where numerous parameters (geomorphologic, land-cover, lithologic) are already known.

\section{Experimental research site and sampling}

The study area corresponds to two experimental watersheds - Le Laval, $0.86 \mathrm{~km}^{2}$ $\left(44^{\circ} 08^{\prime} 33^{\prime \prime} \mathrm{N}, 06^{\circ} 22^{\prime} 05^{\prime \prime} \mathrm{E}\right)$ and Le Brusquet, $1.08 \mathrm{~km}^{2}\left(44^{\circ} 09^{\prime} 46^{\prime \prime} \mathrm{N}, 06^{\circ} 19^{\prime} 38^{\prime \prime} \mathrm{E}\right)$ - located near Digne, Alpes-de-Haute-Provence, France (Mathys, 2006; Fig. 1a). These watersheds 
were chosen because they overlie Jurassic marly bedrocks (Bajocian to Oxfordian age) containing at least $0.5 \%$ of FOC (Artru, 1972). These rocks are also very sensitive to weathering and develop typical badlands morphology with $\mathrm{V}$-shapes gullies, providing highly loaded floods (Mathys et al., 2003).

Le Laval watershed (Fig. 1b) has a poor vegetation density (21\%) mainly composed of grass, graminaceous plants, broom, scots pine and oak overlying Callovo-Oxfordian marly limestones. Le Brusquet watershed (Fig. 1c) is covered extensively (87\%) by scots pine forest overlying Toarcian black shales, upper Aalenian grey shales, lower Aalenian limestones and Bajocian marly limestones.

The investigation focused on representative samples and profiles containing FOC. If FOC is well containing in the sedimentary rocks (five bedrock samples), other assumed FOC reservoirs were also investigated, regolith (five weathering profiles with different rocks and land cover context), riverine particles (eight samples collected at the outlets) and soils (five soil profiles). Some of these analyzed samples have already been studied (Copard et al., 2006).

\subsection{Bedrock samples}

Five samples (T4, Br-2R, Br-6R2, Br-4R2 and L8TO9, Fig. 1b and c) corresponding to the different geological facies outcropping in the watersheds were sampled (Callovo-Oxfordian, Bajocian, upper-Aalenian, lower-Aalenian and Toarcian).

\subsection{Soil profiles}

Five soil profiles were sampled according to geological facies: LA 3 and LA 5 overlie Callovo-Oxfordian marls (Fig. 1b) and are covered by dense or open pine and oak forest, BR4, BR6 and BR10 overlie, respectively, lower Aalenian limestones, upper Aalenian, and Toarcian shales (Fig. 1c). They are covered with dense pine forest. When possible, different soil horizons such as litter layer (OL), fragmentation layer $(\mathrm{OF})$, humic layer $(\mathrm{OH})$ and organo-mineral layer (A) were sampled.

\subsection{Watershed weathering profiles}

Five weathering profiles were sampled according to geological facies. Three originate from Le Laval watershed (A-LAV1, A-LAV2, A-LAV3, Fig. 1a and d) are located on marly Callovo-Oxfordian bedrock. Two profiles from Le Brusquet watershed are located on (i) marly Toarcian bedrock (A-BRV1) and (ii) upper Aalenian bedrock (A-BRV2) (Fig. 1c and d).

A-LAV1 $(60 \mathrm{~cm})$ is a soil/weathered rock (alterite) profile (Fig. 1d) from a flat pasture area. The profile is composed mainly of clay for the first $30 \mathrm{~cm}$, and of a mixture of clay and rock fragments. Ten samples were collected every $6 \mathrm{~cm}$.

A-LAV2 $(30 \mathrm{~cm})$ is an alterite/bedrock profile (Fig. 1d) from a flat area without vegetation. Two types of material were distinguished: compact fragments of rock (pl) and fine and friable elements (tf). Ten samples were collected ( $8 \mathrm{pl}$ and $2 \mathrm{tf})$ every 3 or $4 \mathrm{~cm}$. 
A-LAV3 $(40 \mathrm{~cm})$ is an alterite/bedrock profile (Fig. 1d) from a slope without vegetation area. Seven samples (pl) were taken every 5 or $6 \mathrm{~cm}$.

A-BRV1 $(40 \mathrm{~cm})$ is an soil/alterite profile (Fig. 1d) from a flat wooded area. The profile is composed mainly of a mixture of clay and rock fragments. Ten samples ( $8 \mathrm{pl}$ and $2 \mathrm{tf})$ were collected every $5 \mathrm{~cm}$.

A-BRV2 $(40 \mathrm{~cm})$ is a soil/alterite/bedrock profile (Fig. 1d) from a flat and wooded area. The profile consists of soil horizons (OH and A) for the first $15 \mathrm{~cm}$, followed by $20 \mathrm{~cm}$ of alterite and by bedrock. Seven samples (5 pl and $2 \mathrm{tf})$ were collected every $5 \mathrm{~cm}$.

\subsection{Riverine particles}

Eight riverine particle samples from the two watersheds were sampled according to the season. Four suspended load samples (SL) come from Le Laval watershed stream and were collected using automatic sampling during spring, summer and autumn (LA SL 19/03/01, LA SL 28/04/00, LA SL 15/06/00, LA SL 12/10/00). The SL sample from Le Brusquet watershed was collected during spring (BR SL 15/06/00). Two bed load (BL) samples from Le Laval watershed were also collected during spring and summer (LA BL 28/04/01, LA BL 16/06/00) and one from Le Brusquet watershed during summer (BR BL 28/04/01).

\section{Methods}

\subsection{Optical investigations}

Optical investigations (palynofacies method) were performed with a DMR XP Leica microscope by using the transmitted light mode. Initially developed by Combaz (1964), the palynofacies method consists of a study of thin slides of a total assemblage of particulate organic matter isolated from sedimentary rocks using $\mathrm{HCl}-\mathrm{HF}$. Organic concentrates are then filtered $(250 \mu \mathrm{m})$. The approach involves the distinction of different categories of petrographic components based on their size, form, texture and color, and an estimate of their relative proportions in the particular organic assemblage ( [Combaz, 1980] and [Tyson, 1995] ). Relative quantification was performed with a 50× objective and it is effective when 500 particles are counted, because variations of relative abundances were also lower than $5 \%$ (Sebag et al., 2006a).

Eight categories of organic particles were identified in the samples (Fig. 2a): (i) gelified debris (GD) that have homogeneous contours and textures and show high reflectance under reflected light observations, (ii) cuticle fragments (Cut), (iii) spores and pollen (SP), (iv) mycelium fragments (Myc), (v) lignocelluloses fragments (LC) with recognizable woody structure, (vi) opaque lignocellullose fragments (OLC) not displaying any identifiable structure and showing high reflectance under reflected light observation (R0\% between $1 \%$ and 3\%, Fig. 2b), (vii) corroded outline opaque lignocellullosic fragments (CoOLC) resulting from combustion of biomass during wildfires or human activities (pyrofusinite particles) or resulting from air oxidation without heating prior burial (fusinite particles), (viii) reddish amorphous organic matter (RAOM) consisting of a group of colloidal particles without homogeneous contours and texture with a dark red color under transmitted light (no reflectance). The relative proportion of pyrite (resistant to acid treatment) is also mentioned. 


\subsection{Chemical investigations}

The geochemical signature of the samples was acquired by using Rock-Eval 6 pyrolysis (RE6, Vinci Technologies ()). Previously developed for petroleum purposes and the analysis of sedimentary rocks, the method has been now been successfully tested for recent material ( [Di-Giovanni et al., 1997] , [Di-Giovanni et al., 1998] , [Noël et al., 2001] , [Disnar et al., 2003] , [Copard et al., 2006] and [Sebag et al., 2006b] ).

The protocol consists of two successive stages following a temperature programming of $25{ }^{\circ} \mathrm{C}$ $\mathrm{min}^{-1}$. The first consists of pyrolysis of $100 \mathrm{mg}$ of crushed sample in an oven. Hydrocarbon and oxygenated products released during a temperature increase from 200 to $650{ }^{\circ} \mathrm{C}$ are removed via a $\mathrm{N}_{2}$ flow and quantified with flame ionization and infrared detectors. The second stage consists of an oxidation in an oven and in the presence of air, of the carbonaceous residue subjected to a temperature increase from 400 to $750{ }^{\circ} \mathrm{C}$ ( [Espitalié et al., 1985] and [Lafargue et al., 1998] ).

This analytical method provides a number of parameters such as (i) $T_{\max }\left({ }^{\circ} \mathrm{C}\right)$, the temperature at which the maximum hydrocarbon (HC) release occurs, and (ii) the hydrogen index (HI, in $\mathrm{mg} \mathrm{HC} \mathrm{g}^{-1} \mathrm{TOC}$ ), which can be defined as an indicator of the $\mathrm{H}$ richness of the analyzed sample. The amount of organic $\mathrm{C}(\mathrm{OC})$ is given by the total $\mathrm{O}$ carbon (TOC, expressed in wt $\%$ ), equal to the sum of pyrolysed OC and residual OC provided by the oxidation stage.

\subsection{RE6 pyrolysis signal deconvolution}

For some samples, $\mathrm{S}_{2}$ signals corresponding to $\mathrm{HC}$ compounds released during the pyrolysis stage have been studied previously (Copard et al., 2006). These signals are generally accompanied by shoulders (multilobed signals) corresponding to various HC clusters displaying different thermal stabilities (Disnar et al., 2003). For the present samples, PeakFit software (SPSS $®$ ) was used in order to decompose these $\mathrm{S}_{2}$ signals into elemental gaussians (R2 > 0.99). Each of these gaussians describes the release of $\mathrm{HC}$ clusters having their own $T_{\text {peak }}\left({ }^{\circ} \mathrm{C}\right)$ and can be expressed in a percentage of the $\mathrm{S}_{2}$ signal (Copard et al., 2006).

\subsection{Molecular investigations}

Samples were freeze-dried and crushed before extraction with dichloromethane (DCM). The extract was fractionated using liquid chromatography (alumina and silica column) into saturated, aromatic and polar components with successive elution by pentane and by a mixture of pentane and DCM (Faure et al., 1999). Polar compounds were recovered with methanol/dichloromethane (MeOH/DCM).

Gas chromatography-mass spectrometry (GC-MS) analysis of aliphatic and aromatic hydrocarbons were performed with a HP5890 series II gas chromatograph coupled to an HP5972A mass spectrometer, using a $60 \mathrm{~m}$ DB-5J \& W fused silica column $(0.25 \mathrm{~mm}$ i.d., $0.1 \mu \mathrm{m}$ film thickness). Analyses were carried out for A-LAV1, A-LAV2, A-BRV1 and ABRV2 weathering profiles, associated bedrock and riverine particle samples in order to obtain and compare their molecular geochemical fingerprints. 


\subsection{Isotopic and chemical investigations}

Samples were crushed, decarbonated $\left(\mathrm{H}_{3} \mathrm{PO}_{4}, 1 \mathrm{~N}\right)$, rinsed and air-dried. Because of the possible occurrence of residual carbonate after the $\mathrm{H}_{3} \mathrm{PO}_{4}$ treatment, bedrock and deeper layer soil samples (A layer) were decarbonated a second time with $\mathrm{HCl}(2 \mathrm{~N})$. X-ray diffractograms were used to check the efficiency of decarbonatation. Sample Br-2R, corresponding to Bajocian substratum, was treated $(1 \mathrm{~h})$ with hot concentrated $\mathrm{HCl}$ to removed dolomite, as evidenced with X-ray diffractograms.

Stable $\mathrm{C}$ isotope measurements $\left[\delta^{13} \mathrm{C} \%\right.$ relative to Pee Dee Belemnite (PDB)] and elementary ( $\mathrm{C}$ and $\mathrm{N}, \%$ ) measurements were carried out with a mass spectrometer (VG Isochrom EA). $\delta^{13} \mathrm{C}$ PDB\%o and Graphite IAEA USGS-24 carbon/azote, Sulphanilamide Carlo Erba standards were used for these investigations.

\section{Chemical and optical results}

Chemical data are listed in Table 1 and Table 2 and Fig. 3 and Fig. 4 and the optical data in Fig. 5, Fig. 6, Fig. 7 and Fig. 8. The Rock-Eval results from the soil profiles, bedrocks, riverine particles and A-LAV1 profile have been published previously (Copard et al., 2006).

\subsection{Bedrock samples}

Bedrocks samples are characterized (Fig. 3 and Fig. 4, Table 1) by low TOC values $(<0.7 \%)$, as well as low $\mathrm{HI}$ (between 26 and $129 \mathrm{mg} \mathrm{HC} \mathrm{g}^{-1} \mathrm{TOC}$ ) and $\mathrm{C} / \mathrm{N}$ values (from 6.4 to 13). Samples from Le Brusquet exhibit $T_{\max }>339^{\circ} \mathrm{C}$, while the marly limestone sample from le Laval (Callovo-Oxfordian) exhibits a very low $T_{\max }$ value $\left(211^{\circ} \mathrm{C}\right)$. The $\delta^{13} \mathrm{C}$ values are close to $-26.8 \%$, except for $\mathrm{Br}-2 \mathrm{R}$ and $\mathrm{Br}-6 \mathrm{R} 2$, where values reach $-26.1 \%$ and $-25.2 \%$. The organic particles (Fig. 5) consist mainly of OLC (52-87\%), and only the Callovo-Oxfordian sample from Le Laval differs, with more abundant RAOM and GD particles (respectively $24 \%$ and $10 \%$ ). Pyrite is observed in overall rock samples, the relative proportion varying between $3 \%$ and $32 \%$.

\subsection{Soil profiles}

Litter samples (OL) are characterized (Fig. 3 and Fig. 4, Table 1) by high TOC values (11.3$44.3 \%$ ), high $\mathrm{HI}$ values (364-533 $\mathrm{mg} \mathrm{HC} \mathrm{g}^{-1} \mathrm{TOC}$ ) and high $\mathrm{C} / \mathrm{N}$ ratio value (40-91.3). $T_{\max }$ are close to $335{ }^{\circ} \mathrm{C}$ and $\delta{ }^{13} \mathrm{C}$ values range between $-26.2 \%$ and $-28.4 \%$ (Fig. 3 and Fig. 4 , Table 1). The organic particles (Fig. 5) mainly consist of LC, SP, cuticles and mycelium fragments $(>90 \%)$.

Other soil profile samples are characterized by TOC, HI and C/N values (Fig. 3 and Fig. 4 , Table 1) decreasing with depth and which do not exceed $3.84 \%, 226 \mathrm{mg} \mathrm{HC} \mathrm{g}^{-1} \mathrm{TOC}$ and 17, respectively, in deeper horizons (A layers). $T_{\max }$ values are relatively low in organic layers (320-335 ${ }^{\circ} \mathrm{C}$ for $\mathrm{OL}, \mathrm{OF}$ and $\mathrm{OH}$ samples) and increase significantly in the A layers $\left(>400{ }^{\circ} \mathrm{C}\right.$ for the Le Laval and $340-400{ }^{\circ} \mathrm{C}$ for Le Brusquet samples). $\delta^{13} \mathrm{C}$ values for A layers vary from $-25.2 \%$ to $-26.2 \%$. The organic particles (Fig. 6) consist mainly of LC, SP, cuticles and mycelium fragments, but their relative contribution decreases from upper to lower horizons. Conversely, RAOM, GD and OLC amounts increase with depth and can, respectively, reach $30 \%, 62 \%$ and $42 \%$ in A layers. No significant report of pyrite is noted in soil profiles (except for $1 \%$ in A layers). 


\subsection{Weathering profiles}

Several trends can be seen, depending on the density of plant cover.

Samples from profiles without plant cover (A-LAV2 and A-LAV3) are characterized (Fig. 3 and Fig. 4, Table 2) by low TOC $(<0.7 \%)$, HI ( $\left.<24 \mathrm{mg} \mathrm{HC} \mathrm{g}^{-1} \mathrm{TOC}\right)$ and $\mathrm{C} / \mathrm{N}(<7.3)$ values. $T_{\max }$ values are frequently high $\left(>499^{\circ} \mathrm{C}\right)$ and $\delta^{13} \mathrm{C}$ values vary between $-27.37 \%$ and $-28.4 \%$. The organic particles (Fig. 7) consist mainly of OLC (between 43\%o and 68\%), RAOM (between $8 \%$ and 22\%) and GD (between $11 \%$ and 23\%). All these organic parameters do not show significant trends with depth while pyrite increases from $0 \%$ to $15 \%$.

Profiles underlying significant plant cover (A-LAV1, A-BRV1 and A-BRV2) show different results:

In the A-LAV1 profile (Fig. 3 and Fig. 4, Table 2), TOC decreases from 0 to $35 \mathrm{~cm}$ and then remains constant (1.87\% to near $0.3 \%)$, HI decreases from 178 to $59 \mathrm{mg} \mathrm{HC} \mathrm{g}^{-1} \mathrm{TOC}, \mathrm{C} / \mathrm{N}$ values decrease from 14 to 5.3 and $T_{\max }$ also decreases with depth from $400{ }^{\circ} \mathrm{C}$ to $215{ }^{\circ} \mathrm{C}$. $\delta^{13} \mathrm{C}$ values are close to $-26.3 \%$.

In the A-BRV1 profile (Fig. 3 and Fig. 4, Table 2), the values are more contrasted; compact fragments of rock $(\mathrm{pl})$ samples are characterized by weak TOC content $(<0.12 \%)$ and are totally depleted in hydrogen, but exhibit low $T_{\max }$ values $\left(<265^{\circ} \mathrm{C}\right)$. Other samples are characterized by TOC and HI values decreasing with depth (from $2.39 \%$ to $0.15 \%$, and from 133 to $0 \mathrm{HC} \mathrm{g}^{-1} \mathrm{TOC}$, respectively), while $T_{\max }$ values decrease (from 378 to $250{ }^{\circ} \mathrm{C}$ ), except for sample $7\left(592{ }^{\circ} \mathrm{C}\right)$. The $\delta^{13} \mathrm{C}$ values range between $-26 \%$ and $-27.05 \%$.

In the A-BRV2 profile (Fig. 3 and Fig. 4, Table 2), pl samples are characterized by very low TOC (ca. $0.3 \%$ ), very low HI ( $<6 \mathrm{mg} \mathrm{HC} \mathrm{g}^{-1}$ TOC) and also have some high $T_{\max }$ (from 481 ${ }^{\circ} \mathrm{C}$ to $509{ }^{\circ} \mathrm{C}$ ) values. Other samples are characterized by TOC and HI values decreasing with depth (from $17.7 \%$ to $2.55 \%$ and from 492 to $171 \mathrm{mg} \mathrm{HC} \mathrm{g}^{-1} \mathrm{TOC}$, respectively), while $T_{\max }$ values increase (from 330 to $420{ }^{\circ} \mathrm{C}$ ). The $\delta^{13} \mathrm{C}$ values for all the samples in this profile are close to $-25.2 \%$.

Samples from the A-LAV1, A-BRVI and A-BRV2 profiles show significant amounts of LC, Cut, Myc and SP particles (Fig. 7) that decrease with depth from approximately $25 \%$ to $66 \%$ for the upper samples to $<10 \%$ for the deeper samples. In contrast, OLC particles increase with depth and can reach $>50 \%$ in the deepest samples. GD particles do not exhibit a clear trend as RAOM. Pyrite occurs only in the deepest samples of the profiles $(<1 \%)$.

\subsection{Riverine particles}

The suspended load (SL samples) collected in the Le Brusquet stream shows modest TOC (1.26\%) and $\mathrm{HI}$ (121 $\mathrm{mg} \mathrm{HC} \mathrm{g}^{-1}$ TOC) values, while the bed load sample is characterized by lower TOC (0.72\%) and HI (28 $\mathrm{mg} \mathrm{HC} \mathrm{g}^{-1}$ TOC) values (Fig. 3 and Fig. 4, Table 1).

Samples collected in the Le Laval stream exhibit rather low RE6 values. TOC values vary between $0.50 \%$ and $0.65 \%$ and $\mathrm{HI}$ values between 50 and $75 \mathrm{mg} \mathrm{HC} \mathrm{g}^{-1} \mathrm{TOC}$, independently of the considered season. $T_{\max }$ values of the 2 spring SL samples are close to $200{ }^{\circ} \mathrm{C}(206$ and $212{ }^{\circ} \mathrm{C}$ ), whereas those obtained for summer and autumn are higher, $501{ }^{\circ} \mathrm{C}$ and $358{ }^{\circ} \mathrm{C}$, respectively. Le Laval bed load samples (BL) are characterized by TOC values similar to 
those of SL samples but with lower HI values (close to $30 \mathrm{mg} \mathrm{HC} \mathrm{g}^{-1} \mathrm{TOC}$ ). The $T_{\max }$ value of the BL samples shows similar seasonal trends to the SL samples, $204{ }^{\circ} \mathrm{C}$ for the sample collected in spring and $520{ }^{\circ} \mathrm{C}$ for that sampled during summer. All riverine particles show low $\mathrm{C} / \mathrm{N}$ values (close to 6 ) and $\delta^{13} \mathrm{C}$ values range between $-26.4 \%$ and $-27.3 \%$.

The organic content (Fig. 7) is mainly composed of OLC (average contribution 70\%), GD (between 2\% and 18\%), RAOM (between 1\% and 8\%) and CoOLC (between 0\% and 9\%). Pyrite is systematically present in all samples and represents around $10 \%$ of the counted items.

\section{Molecular characterization}

The studied samples have generally weak rates of extractions $(<100 \mu \mathrm{g} / \mathrm{g})$ with the exception of the A-BRV2 profile sample (Table 2). These rates are very low compared to samples of TOC and show that the majority of FOM are insoluble with acid treatments. It is considered that the extract yield obtained in A-BRV2 is probably higher than those obtained in other samples because this profile is located in woodland.

Only results obtained on the saturated and aromatic hydrocarbon fractions are shown because other studies appear to be adapted to discriminating modern from fossil organic contributions ( [Eglinton et al., 1997] , [Lichtfouse et al., 1997a] , [Lichtfouse et al., 1997b] and [Faure et al., 1999] ).

\subsection{Weathering profiles}

Only the A-BRV1 and A-BRV2 profiles were analyzed because the extract yields of samples from Le Laval profiles were too low (Table 2). Samples from the top of these two profiles (ABRV1 2, A-BRV2 3 tf; Fig. 8a and b) are characterized by a bimodal distribution of $n$-alkanes centered on $\mathrm{C}_{17}$ and $\mathrm{C}_{31}$, and marked by a predominance of odd $\mathrm{C}$ numbers in the $\mathrm{C}_{25}-\mathrm{C}_{31}$ range. On the other hand, bedrock samples (L8TO9 and Br-6R2) show a complex distribution of low molecular weight $n$-, iso- or cyclo alkanes $\left(\mathrm{C}_{16}-\mathrm{C}_{23}\right.$ range), without a predominance of odd or even $\mathrm{C}$ numbers. Intermediate molecular fingerprints were observed for samples ABRV1 6 pl, A-BRV1 6 tf, A-BRV2 4 tf and A-BRV2 4 pl. However, the relative abundance of the higher $n$-alkanes decreases with depth.

Because of very low intensities of the chromatograms, aromatic compounds were only examined for A-BRV1 2, A-BRV2 4 tf and the A-BRV2 4 pl samples. Dehydroabietane and retene were present in A-BRV1-2, and only dehydroabietane in the two A-BRV2 samples. Retene and its precursor dehydroabietane are characteristic of gymnosperms (such as spruces and pines; Otto and Simoneit, 2001).

\subsection{Riverine particles}

Whatever the sampling season, aliphatic hydrocarbons in the SL samples consist of n-alkanes mainly in the $\mathrm{C}_{16}-\mathrm{C}_{22}$ range and marked by an even predominance. Such a distribution corresponds to an algal and/or a microbial contribution. The aromatic hydrocarbon distribution appears to be more complex, with alkyl benzenes, alkyl phenantrenes, alkyl pyrenes and alkyl chrysene. Other aromatic hydrocarbons (norabietatrienes, cadalenes and calamenes) are also present whatever the sampling season, but become predominant in 
summer. Saturated and aromatic hydrocarbon distributions of BL samples are closely similar to those of the SL samples.

\section{Definition of fossil organic markers}

Excepted the measurement sites, the experimental watersheds are devoid of present day human activities. So, the two main OC sources for the studied samples are considered to be: Recent OM (ROM) and Fossil OM (FOM). ROM, inherited from land cover production (vegetation), feeds organic soil horizons and can be stored in deeper soil horizons (A horizons), regolith and can contribute to suspended load. FOM is released during rocks weathering and so can be found in regolith which feeds organo-mineral horizons where a mixing with ROM can arise. In addition, such mixing also occurs in riverine particles since marly bedrocks are considered to be highly erodible and can contribute significantly to the sediment load.

The monitoring of FOM requires the definition of markers, which can be deciphered after the analyses of OM in rocks (FOM) and in litter (ROM) as litter does not contain FOM. In the following paragraphs, a critical analysis of the results is presented in order to choose the investigations that are relevant to clearly discriminate the FOM of the ROM in the studied samples.

\subsection{Non-self sufficient investigations}

Litter and bedrock $\delta^{13} \mathrm{C}$ values are too similar (respectively $-26.2 \%$ to $-28.4 \%$ and $-25.2 \%$ o to $-26.9 \%$ ) to provide a significant discrimination between FOM and ROM. On the other hand, $\mathrm{C} / \mathrm{N}$ and $\mathrm{HI}$ values differ significantly in litter and bedrock samples: high values occurring in the litter samples and low values in bedrock samples. However, soil $\mathrm{HI}$ and $\mathrm{C} / \mathrm{N}$ values generally decrease during pedologic evolution ( [Duchauffour, 2001] and [Disnar et al., 2003] ). So, a low HI or C/N value in A layer samples can either be due to a high proportion of FOM in the studied sample or to some ROM processes (mineralization and humification processes). $T_{\max }$ values are also too scattered in bedrock samples to be considered as discriminatory. TOC values are quite low in bedrock samples and mostly measured during the oxidation stage of the Rock-Eval 6 pyrolysis (i.e. 95\% of TOC is considered as residual OC, see also Section 3.2.). The amount of HC measured by the FID detector during the pyrolysis stage is negligible and explains the low $\mathrm{HI}$ values of bedrocks. The $\mathrm{S}_{2}$ signal is then just above the background noise of the FID detector and could explain the dispersion of some $T_{\max }$ values as seen for sample T4 $\left(T_{\max }=211^{\circ} \mathrm{C}\right)$. For this sample very low $T_{\max }$ value can also be understood as the occurrence of free $\mathrm{HC}$ initially entrapped in the OM structure and rapidly released during pyrolysis.

For these reasons, isotopic, elemental and classical Rock Eval pyrolysis investigations can be considered as not self sufficient to identify FOM or ROM in the studied samples.

\subsection{Representative investigations}

\subsubsection{Molecular investigations}

Molecular investigations clearly show that bedrock organic contents are characterized by an unimodal distribution of $n$-, iso- or cyclo alkanes centered between $\mathrm{C}_{16}$ and $\mathrm{C}_{23}$ without even 
or odd c number predominance. Soil samples are very different and mainly yield n-alkanes centered on $\mathrm{C}_{17}$ and $\mathrm{C}_{31}$ with an odd $\mathrm{C}$ number predominance.

\subsubsection{Optical investigations}

FOM is mainly dominated by opaque particles that can represent $52-87 \%$ of the total items, with ROAM and GD having lower proportions (between $0 \%$ and $24 \%$, and $0 \%$ and $10 \%$, respectively, cf. T4 sample). Such opaque particles are not observed in litter samples (OL, OF and $\mathrm{OH}$ ) but rather originated from some ligno-cellulosic tissues remaining after thermal maturation of organic matter during burial (i.e. vitrinite particles, [Combaz, 1980] and [Tyson, 1995] ). Consequently, this kind of particle would characterize FOM observed in some various outcropping marly bedrocks containing ligno-cellulosic organic matter ( [Di-Giovanni et al., 1997] , [Di-Giovanni et al., 1998] , [Di-Giovanni et al., 1999] , [Di-Giovanni et al., 2000] and [Graz et al., 2010] ). Their significant reflectance under reflected light mode, and the lack of structure inherited from plant precursors discern them from fresh to highly altered soil OM. These particles are thus representative of FOM and the palynofacies method can be considered as a useful tool for the discrimination of ROM from FOM.

\subsubsection{RE6 pyrolysis signal deconvolution}

A first study dealing with the RE6 pyrolysis method has already been published and concerned some samples analyzed in the present study (Copard et al., 2006). In the present work, $\mathrm{S}_{2}$ signals from RE6 pyrolysis (see methods section for details) can be decomposed into six gaussians corresponding to six clusters of OM (F1, F2, F3, F4, F5 and F6, Table 1 and Table 2) characterized by their own $T_{\text {peak }}\left({ }^{\circ} \mathrm{C}\right) . \mathrm{F} 1$, the most labile, and F6, the most refractory towards pyrolysis temperature were found in bedrock OM but are absent in litters layers. Accordingly, these two clusters can be considered as FOM markers (Copard et al., 2006).

\section{Discussion}

Isotopic and classical geochemical investigations $\left(\delta^{13} \mathrm{C}, \mathrm{C} / \mathrm{N}, \mathrm{RE} 6\right.$ parameters $)$ are considered to be indecisive for evidences of FOM occurrence in the studied $\mathrm{C}$ reservoir since possible confusion with ROM may arise. However, data from these non-discriminative methods (see Section 6.1. and Table 1 and Table 2) do not exclude the occurrence of FOM. Hereafter, the focus is mainly on analytical methods which undoubtedly identify FOM.

\subsection{Occurrence of FOM in studied pools}

\subsubsection{Riverine particles}

All investigations (optical, geochemical, elemental, isotopic and molecular) of riverine particles show that the bed and suspended load sample (BL and SL) organic contents are very similar to those of the bedrock. As an example, the occurrence of alkyl benzenes, alkyl phenantrenes, alkyl pyrenes and alkyl chrysenes in riverine samples underlines a bedrock contribution.

\subsubsection{Weathering profiles}

OM quality in the weathering profiles appears to be very close to that of the bedrock as supported by the contribution of opaque particles which can reach $71 \%$. A significant ROM 
contribution only occurs in surface and tf samples from some vegetated profiles (A-LAV1, ABRV1 and A-BRV2). This mixing between FOM and ROM is marked by the occurrence of LC decreasing with depth. This is also evidenced by the predominance of low molecular weight $n$-alkanes at the bottom of the profiles, inherited from FOM, where their relative contribution decreases toward the surface (10-50\% of the initial content). These aliphatic compounds are then replaced by longer n-alkanes, in the $\mathrm{C}_{25}-\mathrm{C}_{31}$ range, with an odd predominance, consistent with some cuticle wax input from higher plants.

FOM markers (F1, F6), described after $\mathrm{S}_{2}$ signal deconvolution, occur at the bottom of the ALAV1 profile, but only F6 is observed along the profile (Copard et al., 2006). F1 disappearance in the A layer samples shows that FOM quality does not remain constant during the transfer from bedrock to soils and persists only in its refractory form.

\subsubsection{Soil profiles}

In soil layers, petrographical signatures show organic material that is a mixture of FOM and ROM, in particular in A layers. Indeed, fossil organic markers are absent in litter layers but are a significant in A layers (opaque particles can range between $0 \%$ and $43 \%$ of the total counted particles).

\subsection{Fate of FOM in pool transitions}

Continental surfaces are subjected to two principal weathering processes, (bio)chemical and mechanical. For the studied watersheds, mechanical weathering corresponds to direct erosion (regressive erosion) of the marls by streams responsible for the observed badlands morphology. Chemical weathering, responsible for the formation of weathering profiles, corresponds to the hydrolysis of the marls by infiltrating water (Campy and Macaire, 1989 and [Campy and Macaire, 2003] ). Under vegetation, biochemical processes are dominant (bacterial activity and infiltrating water) for soil formation.

The results reveal that the direct transfer from bedrock to riverine particles does not alter FOM, both quantitatively and qualitatively. No mineralization of marl OM occurs during regressive erosion.

The bedrock/weathering profile transfer is accompanied by a degradation of the pyrite (optical analysis), but has no significant effect on FOM quality, notably on the profiles without vegetation cover. Chemical weathering seems to have no significant impact on the FOM input to modern environments.

In the soil layers and in the upper layers of the weathering profiles under vegetation, the $\mathrm{OM}$ is a mixture composed of FOM and ROM. From the base to the top of these profiles, the observed decrease of the FOM proportion and low molecular weight $n$-alkanes could mean FOM weathering and/or dilution within ROM. However, the transfer between weathering profiles and soils, marked by strong biological activity, is also accompanied by the disappearance of the F1 cluster. This result clearly illustrates a selective and qualitative weathering of FOM as a result of biochemical processes. 


\subsection{Draix watersheds FOM representativeness}

In soils and recent sediments, FOM and thus FOC can be stored or weathered according to the weathering rate. After erosion, FOM can be conveyed by drainage networks with suspended load and then, can be stored within the floodplains or can reach the ocean. This probability to FOM being weathered, stored or carried to ocean is related to the complex relationships and feedbacks between numerous parameters depending on climate, geology, anthropogenic activities and physico-chemical properties of the FOM (Copard et al., 2007). As a consequence, the results cannot be easily extended to other drainage basins as illustrated by some previous studies on weathering profiles and FOC transfers over continental surfaces. As some examples, Black shale weathering profiles, containing marine- derived OM, exhibit $\mathrm{C}$ losses reaching 60-100\% (Petsch et al., 2000) while coal (OM inherited from higher plants) weathering profiles, exhibiting some variable maturity degrees, show a $\mathrm{C}$ loss comprising between 20\% and 45\% ( [Fredericks et al., 1983] , [Lo and Cardott, 1995] and [Copard et al., 2002] ). It is not surprising that graphite, the ultimate end-member in terms of maturity reached by OM during burial, is considered un-weatherable (Galy et al., 2008). At the scale of the Himalayan range, these same authors concluded that 30-50\% of FOC are preserved during an erosion cycle and eventually buried in sediments.

In the present study, climatic and lithologic forcing drive the landscape to a badlands morphology with the highest erosion rate in the world (Nadal-Romero et al., 2008).

Consequently, FOM residence time in the surface is likely to be insufficient for a significant impact of weathering on the quality of FOM and on the FOC content exported by such ephemeral river networks. In addition to the strong optical and chemical similarities between riverine $\mathrm{OM}$ and bedrock $\mathrm{OM}$, this point is evidenced by the occurrence of pyrite in $\mathrm{OM}$ riverine samples which is considered as highly weatherable (Chang and Berner, 1999). All things being equal, the results can be compared with other drainage basins displaying some similarities in terms of (i) lithology (marls and shales), (ii) FOC contents (0.1-1\%) and (iii) a huge sedimentary load. Thereby, previous works have shown that FOC is a significant fraction of OC sediments loads from mountainous and coastal drainage basins from the USA (e.g. Blair et al., 2003), New Zealand (e.g. Gomez et al., 2003) and Taiwan (Kao and Liu, 1996). At the global scale, sediment loads from mountainous rivers represent $40 \%$ of the total sediment input delivered to the world oceans (20 Gt/a, Milliman and Syvitski, 1992). Consequently, if it is assumed that the average FOC content of such sediments is generally close to $0.5 \mathrm{wt} \%$ (Meybeck, 1993), up to $0.04 \mathrm{Gt} / \mathrm{a}$ of FOC could be exported to marine sediments, with a possible C storage downstream of the river (Blair et al., 2004). In another context such as basins without marked relief, the occurrence of aged organic $\mathrm{C}$ has also been reported in some American rivers ( [Raymond and Bauer, 2001] and [Leithold et al., 2006] ), but the origin (sedimentary rocks vs. ancient soils, Blair et al., 2004) and the fate of this C remains uncertain.

All these examples underline the intricacy of relationships between numerous parameters involved with weathering, preservation and transfer of FOM on continental surfaces. Furthermore, to the authors' knowledge, little work has been reported dealing with FOC transfer within badland areas. Remediation of this is essential to constrain the FOC fluxes (and its storage) within continental surfaces and the role of this $\mathrm{C}$ form within the biogeochemical $\mathrm{C}$ cycle.

\section{Conclusions}


A first field study marked by a "multi-pool-multi-analytical" approach has been carried out. Optical, isotopic, chemical and molecular investigations were conducted in order to determine the FOM contribution to various continental $\mathrm{C}$ reservoirs by considering the weathering profile, soil and riverine loads.

The results highlight the significant contribution of FOM to all the studied compartments. Bedrock/weathering profiles transition (chemical weathering) and bedrock/riverine particles transition (mechanical erosion) involve little or no qualitative and quantitative changes for FOM. In addition, even if a significant FOM contribution is present in A layers, the weathering profile/soil transition provides evidence for a qualitative change of FOM characterized by the disappearance of its most labile fraction.

The results point to the fact that the FOM from continental surfaces resulting from weathering does not simply act as a source of $\mathrm{C}$ to the atmosphere or a direct input in soils or riverine particles. Such a contribution should be taken into account by other studies based on organic matter data, in particular those working on organic stocks and fluxes. In fact, FOM fate appears to be controlled mainly by (i) the nature of the weathering processes (e.g. hydrolysis, bacterial activity), (ii) the duration of exposure and (iii) the physical and chemical properties of FOM that lead to a variation of its sensitivity toward weathering. Further studies should be performed to clarify the role of FOM in the $\mathrm{C}$ cycle in terms of delivery and fate.

\section{Acknowledgements}

This work is a contribution of the GIS 'Bassins de Draix, étude de l'érosion en montagne' driven by the Cemagref and was financially supported by CNRS programme INSU PNSEACI - 'Influence de l'érosion sur les flux de matière organique fossile dans les géosystèmes continentaux actuels (sols, cours d'eau): bassins expérimentaux de Draix, Alpes de Haute Provence, «France». The authors warmly thank N. Mathys, M. Hatton and M.J. Milloux for assistance. We are grateful to the reviewers for constructive comments.

\section{References}

Adams and Faure, 1996 Adams, J., Faure, H., 1996. Changes in moisture balance between glacial and interglacial conditions/influence on carbon cycle processes. In: Brandson, J., Brown, A.G., Gregory, K.J. (Eds.), Global Continental Change: The Context of Paleohydrology. Geological Society of London, Special Publication 115, pp. 27-42..

Adams et al., 1990 J. Adams, H. Faure, L. Faure-Denard, J.M. McGlade and F.I. Woodward, Increases in terrestrial carbon storage from the Late Glacial Maximum to the present. Nature, 348 (1990), pp. 711-714

Aitkenhead and McDowell, 2000 J.A. Aitkenhead and WH. McDowell, Soil C:N ratio as a predictor of annual riverine DOC fluxes at local and global scales. Global Biogeochem. Cycles, 14 (2000), pp. 127-138

Amiotte-Suchet, 1995 Amiotte-Suchet, P., 1995. Cycle du carbone, érosion chimique des continents et transferts vers les océans. In: ULP-CNRS (Ed.), Mémoire Sciences Géologiques, p. 97 .. 
Amiotte-Suchet et al., 2003 P. Amiotte-Suchet, J.L. Probst and W. Ludwig, Worldwide distribution of continental rock lithology: implications for the atmospheric/soil $\mathrm{CO}_{2}$ uptake by continental weathering and alkalinity rivers transport to the oceans. Global Biogeochem. Cycles, 17 (2003).

Artru, 1972 Artru, P., 1972. Les terres noires du basin rhodanien (Bajocien supérieur à oxfordien moyen): stratigraphie, sédimentologie, géochimie). PhD Thesis, Lyon Univ..

Balesdent, 1996 J. Balesdent, The significance of organic separates to carbon dynamics and its modelling in some cultivated soils. Eur. J. Soil Sci., 47 (1996), pp. 485-493.

Batjes, 1996 N.H. Batjes, Total carbon and nitrogen in the soils of the world. Eur. J. Soil Sci., 47 (1996), pp. 141-163.

Bilodeau et al., 1990 G. Bilodeau, A. De Vernal, C. Hillaire-Marcel and H. Josenhans, Post glacial palaeoceanography of Hudson bay: stratigraphic microfaunal and palynological evidence. Can. J. Earth Sci., 27 (1990), pp. 946-963.

Blair et al., 2003 N.E. Blair, E.L. Leithold, S.T. Ford, K.A. Peeler, J.C. Holmes and D.W. Perkey, The persistence of memory: the fate of ancient sedimentary organic carbon in a modern sedimentary system. Geochim. Cosmochim. Acta, 67 (2003), pp. 63-73.

Blair et al., 2004 N.E. Blair, R.L. Leithold and R.C. Aller, From bedrock to burial: the evolution of particulate organic carbon across coupled watershed-continental margin systems. Mar. Chem., 92 (2004), pp. 141-156.

Blair et al., 2010 N.E. Blair, E.L. Leithold, H. Brackley, N. Trustrum, M. Page and L. Childress, Terrestrial sources and export of particulate organic carbon in the Waipaoa sedimentary system: problems, progress and processes. Mar. Geol., 270 (2010), pp. 10-118.

Campy and Macaire, 1989 Campy, M., Macaire, J.-J., 1989. In: Masson, X.Y. (Ed.), Géologie des formations superficielles, Paris..

Campy and Macaire, 2003 M. Campy and J.J. Macaire, Géologie de la Surface. Erosion, Transfert et Stockage dans les Environnements Continentaux, (2nd ed.), Dunod, Paris (2003).

Carter et al., 1997 M.R. Carter, D.A. Angers, E.G. Gregorich and M.A. Bolinder, Organic carbon storage and nitrogen stocks and storage profiles in cool, humid soils of eastern Canada. Can. J. Soils Sci., 77 (1997), pp. 205-210

Chang and Berner, 1999 S. Chang and R.A. Berner, Coal weathering and the geochemical carbon cycle. Geochim. Cosmochim. Acta, 63 (1999), pp. 3301-3310

Combaz, 1964 A. Combaz, Les palynofaciès. Revue de Micropaléontologie, 7 (1964), pp. 205-218.

Combaz, 1980 A. Combaz, Les kérogènes vus au microscope, B. Durand, Editor, Kerogen, Technips, Paris (1980), pp. 55-111. 
Combaz et al., 1977 Combaz, A., Bellet, J., Poulain, C.I., Tissot, C., 1977. Géochimie organique des sédiments marins profonds, mer de Norvège - Mission ORGON 1. CNRS (Ed.), Paris..

Copard et al., 2002 Y. Copard, J.R. Disnar and J.F. Becq-Giraudon, Erroneous maturity assessment given by $T_{\max }$ and HI Rock-Eval parameters on highly mature weathered coals. Int. J. Coal Geol., 49 (2002), pp. 57-65.

Copard et al., 2006 Y. Copard, C. Di-Giovanni, T. Martaud, P. Albéric and J.E. Olivier, Using Rock-Eval 6 pyrolysis for tracking fossil organic carbon in modern environments: implications for the roles of erosion and weathering. Earth Surf. Process.

Landforms, 31 (2006), pp. 135-153

Copard et al., 2007 Y. Copard, P. Amiotte-Suchet and C. Di-Giovanni, Storage and release of fossil organic carbon related to weathering of sedimentary rocks. Earth Planet. Sci.

Lett., 258 (2007), pp. 345-357.

Dai and Fung, 1993 A. Dai and I.Y. Fung, Can climate variability contribute to the "missing" $\mathrm{CO}_{2}$ sink?. Global Biogeochem. Cycles, 7 (1993), pp. 599-609

Degens et al., 1991 E.T. Degens, S. Kempe and J.E. Richey, Biogeochemistry of major world rivers. SCOPE, 42 (1991), pp. 323-344.

Dickens et al., 2004a A.F. Dickens, Y. Gélinas and J.I. Hedges, Physical separation of combustion and rock sources of graphitic black carbon in sediments. Mar. Chem., 92 (2004), pp. 215-223.

Dickens et al., 2004b A.F. Dickens, Y. Gélinas and J.I. Hedges, Reburial of fossil organic carbon in marine sediments. Nature, 427 (2004), pp. 336-339

Di-Giovanni et al., 1997 C. Di-Giovanni, Ph. Bertrand, M. Campy and J.R. Disnar, Contribution de matière organique méso-cénozoïque dans un flux organique terrigène tardi et post-glaciaire (bassin de Chaillexon, Doubs, France). Bull. Soc. Géol. France, 168 (1997), pp. 553-559.

Di-Giovanni et al., 1998 C. Di-Giovanni, J.R. Disnar, V. Bichet, M. Campy and B. Guillet, Geochemichal characterization of soil organic matter and variability of a past glacial detrital organic supply (Chaillexon lake, France). Earth Surf. Process. Landforms, 23 (1998), pp. 1057-1069.

Di-Giovanni et al., 1999 C. Di-Giovanni, J.R. Disnar, M. Campy and J.J. Macaire, Variability of the ancient organic supply in modern humus. Analusis, 27 (1999), pp. 398-402.

Di-Giovanni et al., 2000 C. Di-Giovanni, J.R. Disnar, J.P. Bakyono, D. Keravis, F. Millet and J.E. Olivier, Application de l'étude de la matière organique à l'analyse de l'érosion: exemple du bassin versant du Moulin, dans les terres noires des Alpes de Haute Provence, France. Compt. Rend. Acad. Sci. Paris, 331 (2000), pp. 7-14 
Disnar et al., 2003 J.R. Disnar, B. Guillet, D. Keravis, C. Di-Giovanni and D. Sebag, Soil organic matter (SOM) characterization by Rock-Eval pyrolysis: scope and limitations. Org. Geochem., 34 (2003), pp. 327-343.

Dow, 1977 W.G. Dow, Kerogen studies and geological interpretations. J. Geochem. Explor., 7 (1977), pp. 79-99. Duchauffour, 2001 P. Duchauffour, Introduction à la Science du Sol; Végétation, Environnement, (sixth ed.), Dunod, Paris (2001).

Eglinton et al., 1997 T.I. Eglinton, B.C. Benitez-Nelson, A. Pearson, A.P. McNichol, J.E. Bauer and E.R.M. Druffel, Variability in radiocarbon ages of individual organic compounds from marine sediments. Science, 277 (1997).

Espitalié et al., 1985 J. Espitalié, G. Deroo and F. Marquis, La pyrolyse Rock-Eval et ses applications, Partie 1-2. Revue de l'Institut Français du Pétrole, 40 (1985), pp. 563-579.

Eswaran et al., 1993 H. Eswaran, E. Van Den Berg and P. Reich, Organic carbon in soils of the world. Soil Sci. Soc. Am. J., 57 (1993), pp. 192-194.

Faure et al., 1999 P. Faure, P. Landais and L. Griffault, Behavior of organic matter from Callovian shales during low-temperature. Fuel, 78 (1999), pp. 1515-1525.

Fredericks et al., 1983 P.M. Fredericks, P. Warbrooke and M.A. Wilson, Chemical changes during natural oxidation of high volatile bituminous coal. Org. Geochem., 5 (1983), pp. 8997.

Galy et al., 2008 V. Galy, O. Beyssac, C. France-Lanord and T. Eglinton, Recycling of graphite during Himalayan erosion: a geological stabilization of carbon in the crust.

Science, 322 (2008), pp. 943-945

Gomez et al., 2003 B. Gomez, N.A. Trustrum, D.M. Hicks, K.M. Rogers, M.J. Page and K.R. Tate, Production, storage, and output of particulate organic carbon: Waipaoa River basin, New Zealand. Water Resour. Res., 39 (2003).

Graz et al., 2010 Y. Graz, C. Di-Giovanni, Y. Copard, F. Laggoun-Defarge, M. Boussafir, E. Lallier-Verges, P. Baillif, L. Perdereau and A. Simonneau, Quantitative palynofacies analysis as a new tool to study transfers of fossil organic matter in recent terrestrial environments. Int. J. Coal Geol., 84 (2010), pp. 49-62.

Groot and Groot, 1971 J.J. Groot and C.R. Groot, Horizontal and vertical distribution of pollen and spores in quaternary sequences, B.M. Funnel, W.R. Riedel, Editors, The Micropaleontology of Oceans, Cambridge University Press (1971), pp. 493-504.

Groot et al., 1967 J.J. Groot, C.R. Groot, M. Ewing, L. Burckle and J.R. Connoly, Spores, pollen, diatoms and provenance of the Argentine basin sediments. Prog.

Oceanogr., 4 (1967), pp. 179-217.

Harrison and Broecker, 1993 K. Harrison and W. Broecker, A strategy for estimating the impact of $\mathrm{CO}_{2}$ fertilization on carbon storage. Global Biogeochem. Cycles, 7 (1993), pp. 6980 . 
Hart et al., 1994 G. Hart, M.A. Pasley and W.A. Gregory, Particulate organic matter, maceral facies models, and applications to sequence stratigraphy, A. Traverse, Editor, Sedimentation of Organic Particles, Cambridge University Press (1994), pp. 337-390

Hilton et al., 2008 R.G. Hilton, A. Galy and N. Hovius, Riverine particulate organic carbon from an active mountain belt: importance of landslides. Global Biogeochem.

Cycles, 22 (2008), p. GB1017.

Holland, 1978 H.D. Holland, The Chemistry of Atmosphere and Oceans, Wiley Interscience Publishers (1978).

Houghton, 1991 R.A. Houghton, Tropical deforestation and atmospheric carbon dioxide. Climatic Change, 19 (1991), pp. 99-118.

Houghton, 1998 R.A. Houghton, Missing sinks, feedbacks, and understanding the role of terrestrial ecosystems in the global carbon balance. Global Biogeochem. Cycles, 12 (1998), pp. 25-34.

Houghton, 2005 R.A. Houghton, Aboveground forest biomass and the global carbon balance. Global Change Biol., 11 (2005), pp. 945-958.

IPCC, 2007 IPCC, 2007. Climate change 2007: the physical science basis. In: Salomon, S., Qin, D., Manning, M., Marquis, L., Averyt, K., Tignor, M., Leroy-Miller, H., Zhenlin C. (Eds.), Contribution of Working Group I to the Fourth Assessment. Cambridge University Press, Cambridge, United Kingdom and New York, USA..

Kao and Liu, 1996 S.J. Kao and K.K. Liu, Particulate organic carbon export from a subtropical mountainous river (Lanyang Hsi), in Taiwan. Limnol. Oceanogr., 41 (1996), pp. 1749-1757.

Kaufmann and Stock, 2003 R.K. Kaufmann and J.H. Stock, Testing hypotheses about mechanisms for the unknown carbon sink: a time series analysis. Global Biogeochem. Cycles, 17 (2003), p. 1072.

King et al., 1995 A.W. King, W.R. Emanuel, S.D. Wullschleger and W.M. Post, In search of the missing carbon sink: a model of terrestrial biospheric response to land-use change and atmospheric $\mathrm{CO}_{2}$. Tellus, 47 (1995), pp. 501-519

Komada et al., 2005 T. Komada, E.R.M. Druffel and J. Hwang, Sedimentary rocks as sources of ancient organic carbon to the ocean: An investigation through $\Delta^{14} \mathrm{C}$ and $\delta^{13} \mathrm{C}$ signatures of organic compound classes. Global Biogeochem. Cycles, 19 (2005), p. GB2017

Lafargue et al., 1998 E. Lafargue, F. Marquis and D. Pillot, Rock-Eval 6 applications in hydrocarbon exploration, production and soil contamination studies. Revue de l'Institut Français du Pétrole, 53 (1998), pp. 421-437

Leithold and Blair, 2001 R.L. Leithold and N.E. Blair, Watershed control on the carbon loading of marine sedimentary particles. Geochim. Cosmochim. Acta, 65 (2001), pp. 22312240 . 
Leithold et al., 2006 E.L. Leithold, N.E. Blair and D.W. Perkey, Geomorphologic controls on the age of particulate organic carbon from small mountainous and upland rivers. Global Biogeochem. Cycles, 20 (2006), p. GB3022.

Lichtfouse et al., 1997a E. Lichtfouse, G. Bardoux, A. Mariotti, J. Balesdent, D.C. Ballentine and S.A. Mack, Molecular ${ }^{13} \mathrm{C}$ and ${ }^{14} \mathrm{C}$ evidence for the allochtonous and ancient origin of $\mathrm{C}_{16^{-}}$ $\mathrm{C}_{18}$ n-halkanes in modern soils. Geochim. Cosmochim. Acta, 61 (1997), pp. 1891-1898.

Lichtfouse et al., 1997b E. Lichtfouse, E. Budzinski, P. Garrigues and T.I. Eglinton, Ancient polycyclic aromatic hydrocarbons in modern soils: ${ }^{13} \mathrm{C},{ }^{14} \mathrm{C}$ and biomarkers evidence. Org. Geochem., 26 (1997), pp. 353-359.

Lo and Cardott, 1995 H.B. Lo and B.J. Cardott, Detection of natural weathering of Upper Mc Alester and Woodford shale, Oklahoma. Org. Geochem., 22 (1995), pp. 73-83.

Ludwig, 2001 W. Ludwig, The age of river carbon. Nature News Views, 409 (2001), pp. 466-467.

Ludwig et al., 1996 W. Ludwig, J.L. Probst and S. Kempe, Predicting the oceanic input of organic carbon by continental erosion. Global Biogeochem. Cycles, 10 (1996), pp. 23-41. |

Masiello and Druffel, 2001 C.A. Masiello and E.R.M. Druffel, Carbon isotope geochemistry of the Santa Clara River. Global Biogeochem. Cycles, 15 (2001), pp. 407-416.

Mathys, 2006 Mathys, N., 2006. Analyse et modélisation à différentes échelles des mécanismes d'érosion et de transport de matériaux solides. Cas des petits bassins versants de montagne sur marnes (Draix, Alpes de Haute Provence). PhD Thesis, Institut nationale polytechnique de Grenoble..

Mathys et al., 2003 N. Mathys, S. Brochot, M. Meunier and D. Richard, Erosion quantification in the small marly experimental catchments of Draix (Alpes de Haute Provence, France). Calibration of the ETC rainfall-runoff-erosion model.

CATENA, 50 (2003), pp. 527-548.

Meybeck, 1993 M. Meybeck, Riverine transport of atmospheric carbon: sources, global typology and budget. Water Air Soil Pollut., 70 (1993), pp. 443-463.

Milliman and Syvitski, 1992 J.D. Milliman and J.P.M. Syvitski, Geomorphic/tectonic control of sediment discharge to the ocean: the importance of small mountainous rivers. $J$.

Geol., 100 (1992), pp. 525-544.

Moran et al., 1998 J.E. Moran, U. Fehn and R.T.D. Teng, Variations in 129I/127I ratios in recent marine sediments: evidence for a fossil organic component. Chem. Geol., 152 (1998), pp. 193-203.

Nadal-Romero et al., 2008 E. Nadal-Romero, J. Latron, C. Martí-Bono and D. Regüés, Temporal distribution of suspended sediment transport in a humid Mediterranean badland area: the Araguás catchment, Central Pyrenees. Geomorphology, 97 (2008), pp. 601-616. 
Noël et al., 2001 H. Noël, E. Garbolino, A. Brauer, E. Lallier-Vergès, J.L. de Beaulieu and J.R. Disnar, Human impact and soil erosion during the last 5000 yrs as recorded in lacustrine sedimentary organic matter at Lac d'Annecy, the French Alps. J. Paleolimnol., 25 (2001), pp. 229-244.

Otto and Simoneit, 2001 A. Otto and B.R.T. Simoneit, Chemosystematics and diagenesis of terpenoids in fossil conifer species and sediment from the Eocene Zeitz formation, Saxony, Germany. Geochim. Cosmochim. Acta, 65 (2001), pp. 3505-3527.

Petsch et al., 2000 S.T. Petsch, R.A. Berner and T.I. Eglinton, A field study of the chemical weathering of ancient sedimentary organic matter. Org. Geochem., 31 (2000), pp. 475-487.

Probst, 1992 Probst, J.L., 1992. Géochimie et hydrologie de l'érosion continentale,

Mécanismes, bilan global actuel et fluctuation au cours des 500 derniers millions d'années. In: ULP-CNRS (Ed.), Mémoire Sciences Géologiques $94 .$.

Raymond and Bauer, 2001 P.A. Raymond and J.E. Bauer, Riverine export of aged terrestrial organic matter to the North Atlantic Ocean. Nature, 409 (2001), pp. 497-500

Raymond and Bauer, 2004 P.A. Raymond and J.E. Bauer, Controls on the variability of organic matter and dissolved inorganic carbon ages in northeast US rivers. Mar.

Chem., 92 (2004), pp. 353-366.

Ronov and Yaroshevskiy, 1976 A.B. Ronov and A.A. Yaroshevskiy, A new model for the chemical structure of the earth crust. Geochem. Int., 13 (1976), pp. 1761-1795.

Sarmiento and Sundquist, 1992 J.L. Sarmiento and E.T. Sundquist, Revised budget for the oceanic uptake of anthropogenic carbon dioxide. Nature, 356 (1992), pp. 589-593.

Schimmel, 1994 D.S. Schimmel, Terrestrial ecosystems and the carbon cycle. Global Change Biol., 1 (1994), pp. 77-91.

Sebag et al., 2006a D. Sebag, Y. Copard, C. Di-Giovanni, A. Durand, B. Laignel, S. Ogier and E. Lallier-Verges, Palynofacies as useful tool to study origins and transfers of particulate organic matter in recent terrestrial environments: synopsis and prospect. Earth-Sci.

Rev., 79 (2006), pp. 241-259.

Sebag et al., 2006b D. Sebag, J.R. Disnar, B. Guillet, C. Di Giovanni, E.P. Verrecchia and A. Durand, Monitoring organic matter dynamics in soil profiles by 'Rock-Eval pyrolysis': bulk characterization and quantification of degradation. Eur. J. Soil Sci., 57 (2006), pp. 344-355.

Tans et al., 1990 P.P. Tans, I.Y. Fung and T. Takahashi, Observational constraints on the global atmospheric $\mathrm{CO}_{2}$ budget. Science, 247 (1990), pp. 1431-1438

Truswell and Drewry, 1984 E.M. Truswell and D.J. Drewry, Distribution and provenance of recycled palynomorphs in surficial sediments of the Ross sea, Antartica. Mar.

Geol., 59 (1984), pp. 187-214

Tyson, 1995 R.V. Tyson, Sedimentary Organic Matter: Organic Facies and Palynofacies, Chapman and Hall, London (1995). 
Wakeham et al., 2004 S.G. Wakeham, J. Forrest, C. Masiello, Y. Gaelinas, C. Alexander and P. Leavitt, Hydrocarbons in Lake Washington sediments. A 25-year retrospective in an urban lake. Environ. Sci. Technol., 38 (2004), pp. 431-439.

Watson et al., 1990 R.T. Watson, H. Rodhe, H. Oeschger and U. Siegenthaler, Greenhouse gases and aerosols, J.T. Houghton, G.J. Jenkins, J.J. Ephraums, Editors, Climate Change: the IPCC Scientific Assessment, Cambridge University Press (1990), pp. 1-40. 
(a)

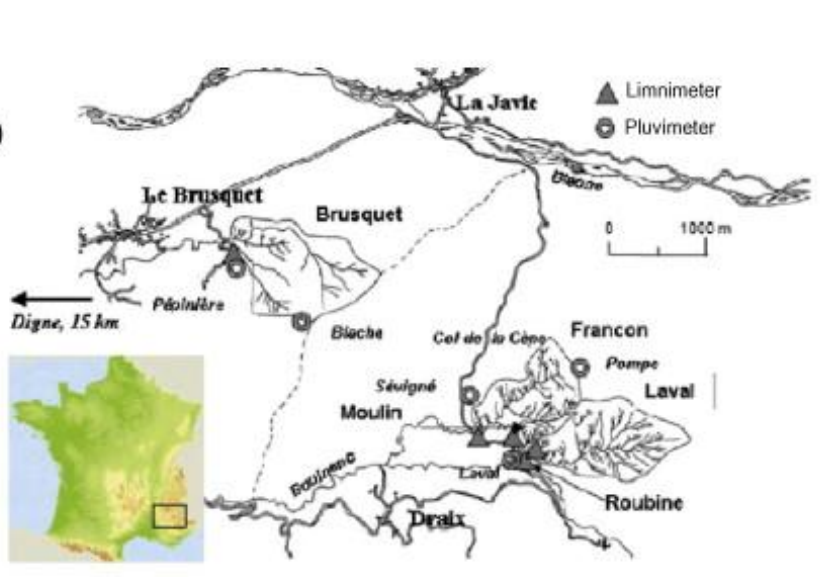

(b) Le Laval watershed

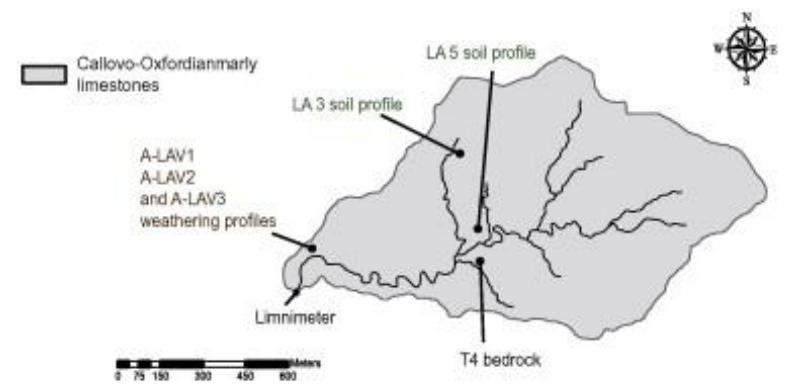

(c) Le Brusquet watershed

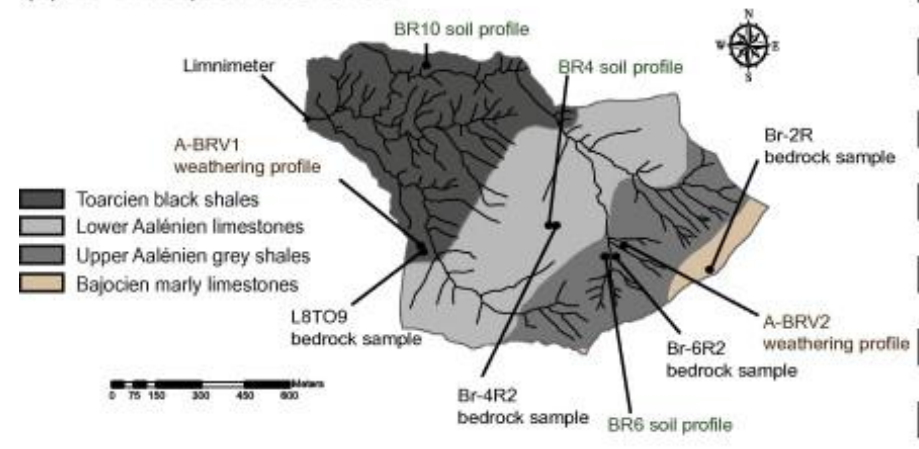

(d) Weathering profiles

Le Laval watershed

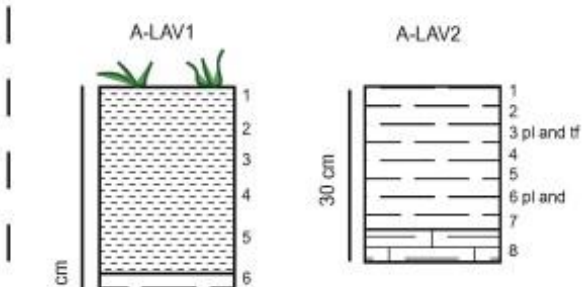

8

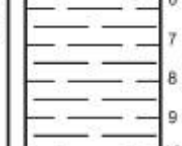

A-LAV3

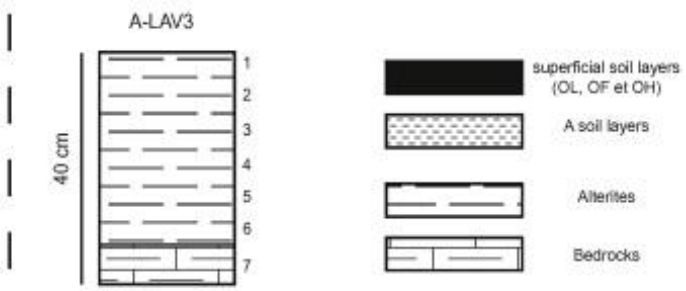

Le Brusquet watershed
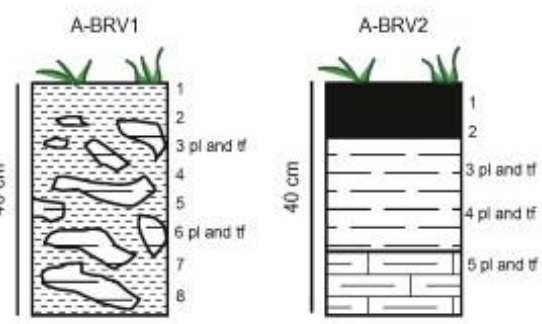

Fig. 1. :Experimental research site: (a) geographical location of experimental watersheds of Draix (Mathys, 2006); (b) Le Laval watershed samples location; (c) Le Brusquet watershed samples location; (d) schematic weathering profiles studied. OL: litter layers; OF: fragmentation layers; $\mathrm{OH}$ : humic layers; A: organo-mineral layers; $\mathrm{pl}$ : compact fragments of rock samples; tf: fine and friable elements. 
(a) Organic particles under transmitted light

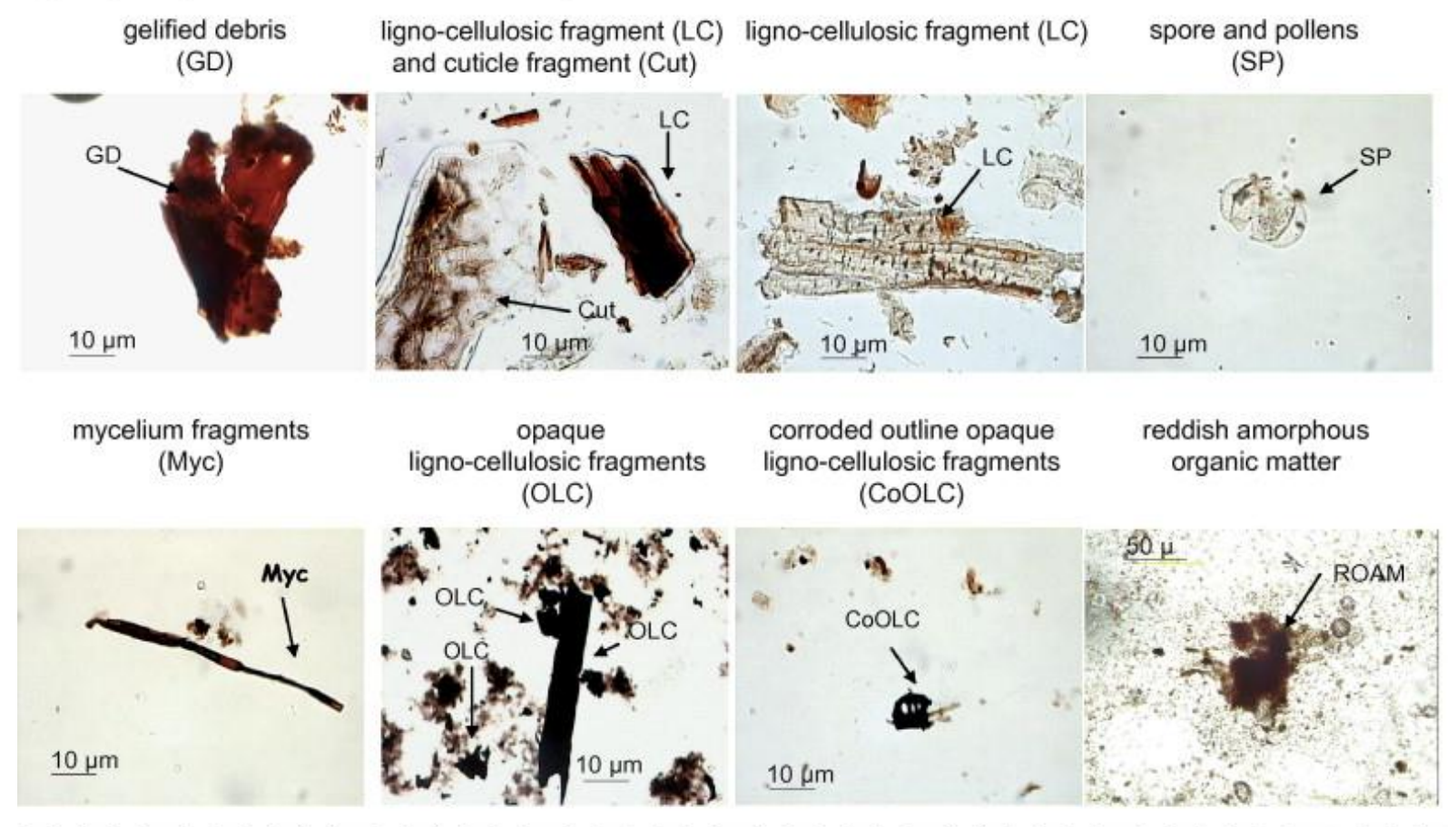

(b) Opaque lignocellullose fragments (OLC) under reflected light
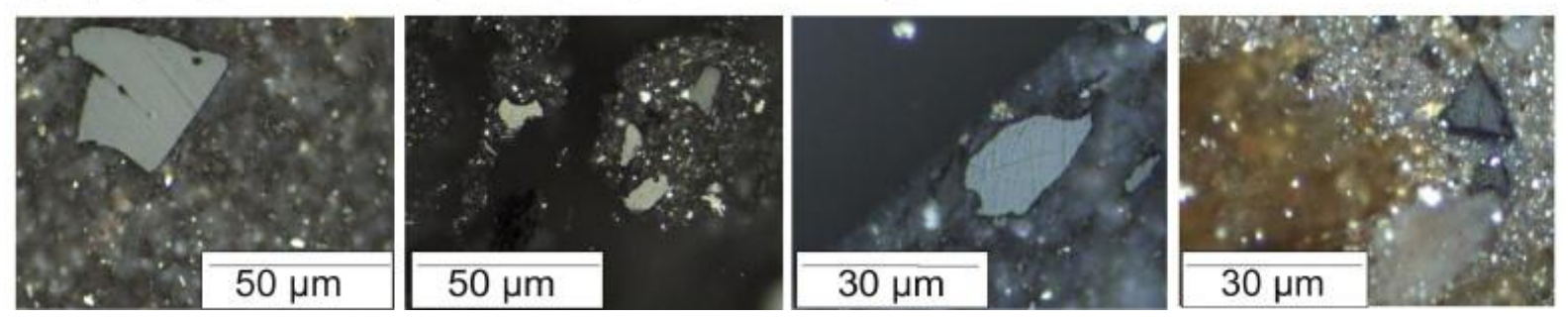

Fig. 2. : (a) Categories of particulate organic matter distinguished from morphological criteria (transmitted light): gelified debris (GD); cuticular fragments (Cut); spore and pollen (SP); mycelium fragments (Myc); lignocellullose fragments (LC); opaque lignocellullose fragments (OLC), fragments that do not display any identifiable structure as well as any fluorescence under UV excitation; corroded outline opaque lignocellullose fragments (CoOLC); reddish amorphous organic matter (RAOM); (b) opaque lignocellullose fragments (OLC) not displaying any identifiable structure and showing very high reflectance via reflected light observation (polished sections). 
Table 1. Results for bedrock, soil profile and riverine particle samples [NB Rock-Eval parameters and $S_{2}$ signal deconvolution (bold characters) are from Copard et al., 2006]. $O L$ : litter layers; OF: fragmentation layers; OH: humic layers; A: organo-mineral layers; SL:suspended load; BL: bed load.

\begin{tabular}{|c|c|c|c|c|c|c|c|c|c|c|c|c|c|c|c|c|c|}
\hline $\begin{array}{l}\text { Sampl } \\
\text { e }\end{array}$ & $\begin{array}{l}\boldsymbol{T}_{\mathrm{ma}} \\
\mathrm{x} \\
\left({ }^{\circ} \mathrm{C}\right. \\
)\end{array}$ & $\begin{array}{l}\text { TO } \\
\text { C } \\
(\%)\end{array}$ & $\begin{array}{l}\text { IH } \\
(\mathbf{H C} \\
\mathbf{g}^{-1} \\
\mathbf{C O} \\
\mathbf{T})\end{array}$ & $\begin{array}{l}\mathrm{C} \\
(\%)\end{array}$ & $\begin{array}{l}\mathbf{N} \\
(\% \\
)\end{array}$ & $\mathrm{C} / \mathrm{N}$ & $\begin{array}{l}\partial^{13} \mathrm{C} \\
(\%)\end{array}$ & $\begin{array}{l}\mathbf{F 1} \\
(\%)\end{array}$ & $\begin{array}{l}\mathrm{F} 2 \\
(\%)\end{array}$ & $\begin{array}{l}\mathbf{F 3} \\
(\%)\end{array}$ & $\begin{array}{l}\mathbf{F 4} \\
(\%)\end{array}$ & $\begin{array}{l}\text { F5 } \\
(\%)\end{array}$ & $\begin{array}{l}\text { F6 } \\
(\%)\end{array}$ & $\begin{array}{l}\text { Rate of } \\
\text { extracti } \\
\text { on } \\
(\mu \mathrm{g} / \mathrm{g})\end{array}$ & $\begin{array}{l}\text { Saturated } \\
\text { hydrocarbo } \\
\text { ns (\%) }\end{array}$ & $\begin{array}{l}\text { Aromatic } \\
\text { hydrocarbo } \\
\text { ns (\%) }\end{array}$ & $\begin{array}{l}\text { Polar } \\
\text { hydrocarbo } \\
\text { ns (\%) }\end{array}$ \\
\hline \multicolumn{18}{|c|}{ Bedrocks } \\
\hline $\mathrm{T} 4$ & 211 & 0.57 & 75 & 0.64 & $\begin{array}{l}0.0 \\
8\end{array}$ & 8.00 & \begin{tabular}{|l}
-26.7 \\
0
\end{tabular} & \begin{tabular}{|l|}
35.0 \\
0
\end{tabular} & 0.00 & $\begin{array}{l}47.5 \\
0\end{array}$ & $\begin{array}{l}11.0 \\
0\end{array}$ & 0.00 & 6.50 & & & & \\
\hline $\mathrm{Br}-2 \mathrm{R}$ & 366 & 0.14 & 129 & 0.26 & \begin{tabular}{|l|}
0.0 \\
3 \\
\end{tabular} & 8.60 & \begin{tabular}{|l|}
-25.2 \\
0
\end{tabular} & 2.00 & $\begin{array}{l}17.5 \\
0\end{array}$ & 0.00 & $\begin{array}{l}\text { 69.0 } \\
0\end{array}$ & 9.00 & 2.50 & & & & \\
\hline $\mathrm{Br}-6 \mathrm{R} 2$ & 343 & 0.50 & 52 & 0.51 & $\begin{array}{l}0.0 \\
9\end{array}$ & 6.40 & \begin{tabular}{|l}
-26.1 \\
0
\end{tabular} & 2.00 & $\begin{array}{l}19.0 \\
0\end{array}$ & \begin{tabular}{|l}
32.0 \\
0
\end{tabular} & $\begin{array}{l}35.0 \\
0\end{array}$ & 8.00 & 0.00 & 1274.60 & 1.00 & 0.40 & 98.60 \\
\hline $\mathrm{Br}-4 \mathrm{R} 2$ & 409 & 0.11 & 55 & 0.13 & $\begin{array}{l}0.0 \\
1\end{array}$ & $\begin{array}{l}13.0 \\
0\end{array}$ & \begin{tabular}{|l}
-26.7 \\
0
\end{tabular} & 4.50 & $\begin{array}{l}21.0 \\
0\end{array}$ & $\begin{array}{l}20.0 \\
0\end{array}$ & $\begin{array}{l}23.0 \\
0\end{array}$ & \begin{tabular}{|l|}
23.5 \\
0
\end{tabular} & 8.00 & & & & \\
\hline L8tO9 & 339 & 0.70 & 26 & 0.75 & \begin{tabular}{|l|}
0.1 \\
0 \\
\end{tabular} & 7.50 & \begin{tabular}{|l|}
-26.9 \\
0 \\
\end{tabular} & \begin{tabular}{|l|}
29.0 \\
0
\end{tabular} & \begin{tabular}{|l|}
23.5 \\
0
\end{tabular} & \begin{tabular}{|l|}
47.5 \\
0
\end{tabular} & 0.00 & 0.00 & 0.00 & 28.80 & 41.00 & 18.10 & 40.90 \\
\hline \multicolumn{18}{|c|}{ Soil profiles } \\
\hline $\begin{array}{l}\text { LA3- } \\
\text { OL }\end{array}$ & 335 & \begin{tabular}{|l|}
42.9 \\
4
\end{tabular} & 505 & \begin{tabular}{|l|}
36.5 \\
0
\end{tabular} & $\begin{array}{l}0.4 \\
0\end{array}$ & $\begin{array}{l}91.2 \\
5\end{array}$ & \begin{tabular}{|l}
-26.2 \\
0
\end{tabular} & 0.00 & $\begin{array}{l}41.5 \\
0\end{array}$ & \begin{tabular}{|l|}
35.5 \\
0
\end{tabular} & 3.00 & \begin{tabular}{|l|}
20.0 \\
0
\end{tabular} & 0.00 & & & & \\
\hline $\begin{array}{l}\text { LA3- } \\
\text { OF }\end{array}$ & 322 & \begin{tabular}{|l|}
36.4 \\
5
\end{tabular} & 403 & & & & & 0.00 & \begin{tabular}{|l|}
32.0 \\
0
\end{tabular} & \begin{tabular}{|l|}
33.0 \\
0
\end{tabular} & $\begin{array}{l}18.0 \\
0\end{array}$ & $\begin{array}{l}17.0 \\
0\end{array}$ & 0.00 & & & & \\
\hline $\begin{array}{l}\text { LA3- } \\
\mathrm{OH}\end{array}$ & 321 & \begin{tabular}{|l}
31.2 \\
6
\end{tabular} & 317 & & & & & 0.00 & $\begin{array}{l}16.0 \\
0\end{array}$ & $\begin{array}{l}35.0 \\
0\end{array}$ & $\begin{array}{l}25.5 \\
0\end{array}$ & $\begin{array}{l}14.5 \\
0\end{array}$ & 9.00 & & & & \\
\hline LA3-A & \begin{tabular}{|l|}
416 \\
\end{tabular} & 2.91 & 226 & 4.30 & $\begin{array}{l}0.3 \\
4\end{array}$ & $\begin{array}{l}12.6 \\
5\end{array}$ & \begin{tabular}{|l|}
-25.8 \\
0
\end{tabular} & 0.00 & \begin{tabular}{|l}
12.0 \\
0
\end{tabular} & $\begin{array}{l}19.0 \\
0\end{array}$ & $\begin{array}{l}25.0 \\
0\end{array}$ & \begin{tabular}{|l}
31.0 \\
0
\end{tabular} & \begin{tabular}{|l|}
13.0 \\
0
\end{tabular} & & & & \\
\hline $\begin{array}{l}\text { LA5- } \\
\text { OL }\end{array}$ & 332 & \begin{tabular}{|l|}
40.0 \\
5 \\
\end{tabular} & 425 & \begin{tabular}{|l}
37.9 \\
0
\end{tabular} & $\begin{array}{l}0.4 \\
8\end{array}$ & \begin{tabular}{|l}
79.0 \\
0
\end{tabular} & \begin{tabular}{|l|}
-27.5 \\
0
\end{tabular} & 0.00 & \begin{tabular}{|l|}
33.5 \\
0
\end{tabular} & \begin{tabular}{|l|}
33.5 \\
0 \\
\end{tabular} & $\begin{array}{l}13.0 \\
0\end{array}$ & $\begin{array}{l}20.0 \\
0\end{array}$ & 0.00 & & & & \\
\hline $\begin{array}{l}\text { LA5- } \\
\text { OH-A }\end{array}$ & 324 & 5.00 & 254 & & & & & 0.00 & 6.00 & \begin{tabular}{|l|}
34.0 \\
0
\end{tabular} & \begin{tabular}{|l|}
28.0 \\
0
\end{tabular} & \begin{tabular}{|l}
16.0 \\
0
\end{tabular} & \begin{tabular}{|l|}
16.0 \\
0
\end{tabular} & & & & \\
\hline LA5-A & 401 & 1.90 & 157 & 1.90 & \begin{tabular}{|l}
0.2 \\
0
\end{tabular} & \begin{tabular}{|l}
10.0 \\
0
\end{tabular} & \begin{tabular}{|l|}
-25.8 \\
0
\end{tabular} & 0.00 & $\begin{array}{l}11.0 \\
0\end{array}$ & $\begin{array}{l}25.5 \\
0\end{array}$ & $\begin{array}{l}26.5 \\
0\end{array}$ & \begin{tabular}{|l|}
20.0 \\
0
\end{tabular} & \begin{tabular}{|l|}
17.0 \\
0
\end{tabular} & & & & \\
\hline $\begin{array}{l}\text { BR4- } \\
\text { OL }\end{array}$ & 335 & \begin{tabular}{|l|}
44.3 \\
4
\end{tabular} & 446 & \begin{tabular}{|l|}
39.4 \\
0 \\
\end{tabular} & \begin{tabular}{|l|}
0.4 \\
4
\end{tabular} & $\begin{array}{l}90.0 \\
0\end{array}$ & \begin{tabular}{|l}
-26.2 \\
0 \\
\end{tabular} & 0.00 & \begin{tabular}{|l|}
35.0 \\
0
\end{tabular} & \begin{tabular}{|l|}
33.0 \\
0
\end{tabular} & 5.00 & $\begin{array}{l}27.0 \\
0\end{array}$ & 0.00 & & & & \\
\hline $\begin{array}{l}\text { BR4- } \\
\text { OF }\end{array}$ & 330 & \begin{tabular}{|l|}
36.7 \\
7 \\
\end{tabular} & 416 & & & & & 0.00 & \begin{tabular}{|l|}
31.5 \\
0
\end{tabular} & \begin{tabular}{|l|}
34.0 \\
\end{tabular} & $\begin{array}{l}12.5 \\
0\end{array}$ & $\begin{array}{l}17.0 \\
0\end{array}$ & 5.00 & & & & \\
\hline $\begin{array}{l}\text { BR4- } \\
\text { OH }\end{array}$ & 324 & \begin{tabular}{|l|}
22.2 \\
3
\end{tabular} & 322 & & & & & 0.00 & $\begin{array}{l}29.0 \\
0\end{array}$ & $\begin{array}{l}35.5 \\
0\end{array}$ & $\begin{array}{l}13.0 \\
0\end{array}$ & $\begin{array}{l}17.0 \\
0\end{array}$ & 5.50 & & & & \\
\hline BR4-A & 338 & 2.51 & 203 & 3.00 & $\begin{array}{l}0.1 \\
8\end{array}$ & \begin{tabular}{|l}
17.0 \\
0
\end{tabular} & \begin{tabular}{|l|}
-26.2 \\
0
\end{tabular} & 0.00 & \begin{tabular}{|l}
22.0 \\
0
\end{tabular} & \begin{tabular}{|l|}
33.0 \\
\end{tabular} & $\begin{array}{l}13.5 \\
0\end{array}$ & \begin{tabular}{|l|}
26.0 \\
0
\end{tabular} & 5.50 & & & & \\
\hline $\begin{array}{l}\text { BR6- } \\
\text { OL }\end{array}$ & 318 & \begin{tabular}{|l}
39.7 \\
3
\end{tabular} & 364 & \begin{tabular}{|l|}
20.4 \\
0
\end{tabular} & \begin{tabular}{|l|}
0.2 \\
7
\end{tabular} & \begin{tabular}{|l}
76.0 \\
0
\end{tabular} & \begin{tabular}{|l|}
-28.4 \\
0
\end{tabular} & 0.00 & $\begin{array}{l}39.5 \\
0\end{array}$ & \begin{tabular}{|l|}
35.0 \\
\end{tabular} & $\begin{array}{l}13.5 \\
0\end{array}$ & \begin{tabular}{|l}
12.0 \\
0
\end{tabular} & 0.00 & & & & \\
\hline $\begin{array}{l}\text { BR6- } \\
\text { OF }\end{array}$ & 332 & \begin{tabular}{|l}
25.3 \\
2
\end{tabular} & 340 & & & & & 0.00 & \begin{tabular}{|l}
28.5 \\
0
\end{tabular} & \begin{tabular}{|l|}
30.0 \\
0
\end{tabular} & $\begin{array}{l}22.0 \\
0\end{array}$ & $\begin{array}{l}17.5 \\
0\end{array}$ & 2.00 & & & & \\
\hline $\begin{array}{l}\text { BR6- } \\
\text { A1 }\end{array}$ & 404 & 1.82 & 182 & 2.40 & \begin{tabular}{|l}
0.2 \\
0
\end{tabular} & $\begin{array}{l}12.0 \\
0\end{array}$ & \begin{tabular}{|l|}
-25.2 \\
0
\end{tabular} & 0.00 & \begin{tabular}{|l}
25.0 \\
0
\end{tabular} & \begin{tabular}{|l} 
23.0 \\
0
\end{tabular} & $\begin{array}{l}31.5 \\
0\end{array}$ & $\begin{array}{l}19.0 \\
0\end{array}$ & 2.00 & & & & \\
\hline $\begin{array}{l}\text { BR10- } \\
\text { OL }\end{array}$ & 332 & \begin{tabular}{|l|}
11.9 \\
1
\end{tabular} & 533 & \begin{tabular}{|l|}
33.3 \\
0
\end{tabular} & \begin{tabular}{|l|}
0.8 \\
4
\end{tabular} & \begin{tabular}{|l|}
40.0 \\
0
\end{tabular} & \begin{tabular}{|l|}
-27.7 \\
0
\end{tabular} & 0.00 & \begin{tabular}{|l|}
33.0 \\
0
\end{tabular} & \begin{tabular}{|l|}
32.0 \\
0
\end{tabular} & $\begin{array}{l}13.0 \\
0\end{array}$ & \begin{tabular}{|l|}
23.0 \\
0
\end{tabular} & 0.00 & & & & \\
\hline $\begin{array}{l}\text { BR10- } \\
\text { A1 }\end{array}$ & 339 & 3.84 & 223 & 5.20 & $\begin{array}{l}0.3 \\
4\end{array}$ & $\begin{array}{l}15.0 \\
0\end{array}$ & $\begin{array}{l}-26.0 \\
0\end{array}$ & 0.00 & $\begin{array}{l}14.0 \\
0\end{array}$ & \begin{tabular}{|l} 
34.0 \\
0
\end{tabular} & $\begin{array}{l}22.0 \\
0\end{array}$ & $\begin{array}{l}17.0 \\
0\end{array}$ & \begin{tabular}{|l}
13.0 \\
0
\end{tabular} & & & & \\
\hline \multicolumn{18}{|c|}{ Riverine particles } \\
\hline $\begin{array}{l}\text { LA SL } \\
19 / 03 / 0 \\
1\end{array}$ & 206 & 0.56 & 50 & 0.67 & $\begin{array}{l}0.1 \\
0\end{array}$ & 7.00 & \begin{tabular}{|l}
-27.0 \\
0
\end{tabular} & $\begin{array}{l}19.0 \\
0\end{array}$ & $\begin{array}{l}10.0 \\
0\end{array}$ & 0.00 & $\begin{array}{l}\text { 65.0 } \\
0\end{array}$ & \begin{tabular}{|l}
20.5 \\
0
\end{tabular} & 3.00 & & & & \\
\hline
\end{tabular}




\begin{tabular}{|c|c|c|c|c|c|c|c|c|c|c|c|c|c|c|c|c|c|}
\hline $\begin{array}{l}\text { Sampl } \\
\text { e }\end{array}$ & $\begin{array}{l}T_{\text {ma }} \\
\text { x } \\
\left({ }^{\circ} \mathbf{C}\right. \\
)\end{array}$ & $\begin{array}{l}\text { TO } \\
\text { C } \\
(\%)\end{array}$ & $\begin{array}{l}\text { IH } \\
(\mathbf{H C} \\
\mathbf{g}^{-1} \\
\mathbf{C O} \\
\mathbf{T})\end{array}$ & $\begin{array}{l}\mathrm{C} \\
(\%)\end{array}$ & $\begin{array}{l}\mathbf{N} \\
(\% \\
)\end{array}$ & $\mathbf{C} / \mathbf{N}$ & $\begin{array}{l}\partial^{13} \mathrm{C} \\
(\%)\end{array}$ & $\begin{array}{l}F 1 \\
(\%)\end{array}$ & $\begin{array}{l}\text { F2 } \\
(\%)\end{array}$ & $\begin{array}{l}\mathbf{F 3} \\
(\%)\end{array}$ & $\begin{array}{l}\mathrm{F} 4 \\
(\%)\end{array}$ & $\begin{array}{l}\text { F5 } \\
(\%)\end{array}$ & $\begin{array}{l}\text { F6 } \\
(\%)\end{array}$ & $\begin{array}{l}\text { Rate of } \\
\text { extracti } \\
\text { on } \\
(\mu \mathrm{g} / \mathrm{g})\end{array}$ & $\begin{array}{l}\text { Saturated } \\
\text { hydrocarbo } \\
\text { ns (\%) }\end{array}$ & $\begin{array}{l}\text { Aromatic } \\
\text { hydrocarbo } \\
\text { ns }(\%)\end{array}$ & $\begin{array}{l}\text { Polar } \\
\text { hydrocarbo } \\
\text { ns (\%) }\end{array}$ \\
\hline $\begin{array}{l}\text { LA SL } \\
28 / 04 / 0 \\
0\end{array}$ & 212 & 0.61 & 74 & 0.73 & $\begin{array}{l}0.1 \\
0\end{array}$ & 7.00 & $\begin{array}{l}-26.4 \\
0\end{array}$ & $\begin{array}{l}27.5 \\
0\end{array}$ & 0.50 & $\begin{array}{l}27.0 \\
0\end{array}$ & $\begin{array}{l}21.0 \\
0\end{array}$ & $\begin{array}{l}10.0 \\
0\end{array}$ & $\begin{array}{l}14.0 \\
0\end{array}$ & & & & \\
\hline $\begin{array}{l}\text { LA SL } \\
15 / 06 / 0 \\
0\end{array}$ & 358 & 0.64 & 61 & 0.70 & $\begin{array}{l}0.0 \\
9\end{array}$ & 8.00 & $\begin{array}{l}-26.7 \\
0\end{array}$ & $\begin{array}{l}25.0 \\
0\end{array}$ & 0.00 & $\begin{array}{l}45.5 \\
0\end{array}$ & 0.00 & $\begin{array}{l}11.0 \\
0\end{array}$ & $\begin{array}{l}17.5 \\
0\end{array}$ & & & & \\
\hline $\begin{array}{l}\text { LA SL } \\
12 / 10 / 0 \\
0\end{array}$ & 501 & 0.55 & 49 & 0.69 & $\begin{array}{l}0.1 \\
1\end{array}$ & 7.00 & \begin{tabular}{|l|}
-27.0 \\
0
\end{tabular} & $\begin{array}{l}18.0 \\
0\end{array}$ & 6.50 & \begin{tabular}{|l|}
38.5 \\
0
\end{tabular} & 0.00 & 7.50 & $\begin{array}{l}29.5 \\
0\end{array}$ & & & & \\
\hline $\begin{array}{l}\text { BR SL } \\
15 / 06 / 0 \\
0\end{array}$ & 407 & 1.27 & 120 & 1.60 & $\begin{array}{l}0.2 \\
7\end{array}$ & 6.00 & $\begin{array}{l}-26.9 \\
0\end{array}$ & 1.50 & $\begin{array}{l}10.0 \\
0\end{array}$ & 0.00 & $\begin{array}{l}65.0 \\
0\end{array}$ & $\begin{array}{l}20.5 \\
0\end{array}$ & 3.00 & & & & \\
\hline $\begin{array}{l}\text { LA BL } \\
28 / 04 / 0 \\
1\end{array}$ & 204 & 0.50 & 28 & 0.51 & $\begin{array}{l}0.0 \\
7\end{array}$ & 7.00 & $\begin{array}{l}-26.8 \\
0\end{array}$ & \begin{tabular}{|l|}
50.5 \\
0
\end{tabular} & 0.50 & $\begin{array}{l}27.0 \\
0\end{array}$ & $\begin{array}{l}21.0 \\
0\end{array}$ & $\begin{array}{l}10.0 \\
0\end{array}$ & $\begin{array}{l}45.5 \\
0\end{array}$ & & & & \\
\hline $\begin{array}{l}\text { LA BL } \\
16 / 06 / 0 \\
0\end{array}$ & 520 & 0.47 & 32 & 0.54 & $\begin{array}{l}0.0 \\
8\end{array}$ & 7.00 & \begin{tabular}{|l}
-27.3 \\
0
\end{tabular} & $\begin{array}{l}27.2 \\
0\end{array}$ & 0.00 & $\begin{array}{l}45.5 \\
0\end{array}$ & 0.00 & $\begin{array}{l}11.0 \\
0\end{array}$ & $\begin{array}{l}67.0 \\
0\end{array}$ & & & & \\
\hline $\begin{array}{l}\text { BR BL } \\
28 / 04 / 0 \\
1\end{array}$ & 365 & 0.72 & 35 & 0.77 & $\begin{array}{l}0.1 \\
0\end{array}$ & 8.00 & $\begin{array}{l}-26.9 \\
0\end{array}$ & $\begin{array}{l}15.5 \\
0\end{array}$ & $\begin{array}{l}10.0 \\
0\end{array}$ & 0.00 & $\begin{array}{l}65.0 \\
0\end{array}$ & $\begin{array}{l}20.5 \\
0\end{array}$ & 4.50 & & & & \\
\hline
\end{tabular}


Table 2. Results for weathering profile samples [NB A-LAV1 Rock-Eval parameters and $\mathrm{S}_{2}$ signal deconvolution (bold characters) are from Copard et al., 2006]. pl: compact fragments of rock samples; tf: fine and friable elements.

\begin{tabular}{|c|c|c|c|c|c|c|c|c|c|c|c|c|c|c|c|c|c|}
\hline $\begin{array}{l}\text { Sampl } \\
\text { e }\end{array}$ & $\begin{array}{l}\boldsymbol{T}_{\mathrm{ma}} \\
\mathrm{x} \\
\left({ }^{\circ} \mathrm{C}\right. \\
)\end{array}$ & $\begin{array}{l}\text { TO } \\
\text { C } \\
(\%)\end{array}$ & \begin{tabular}{|l} 
IH \\
$(\mathbf{H C}$ \\
$\mathbf{g}^{-1}$ \\
COT \\
)
\end{tabular} & $\begin{array}{l}\text { C } \\
(\% \\
)\end{array}$ & $\begin{array}{l}\mathbf{N} \\
(\% \\
)\end{array}$ & $\mathrm{C} / \mathrm{N}$ & $\begin{array}{l}\partial^{13} \mathrm{C} \\
(\%)\end{array}$ & $\begin{array}{l}\text { F1 } \\
(\%)\end{array}$ & $\begin{array}{l}\text { F2 } \\
(\% \\
)\end{array}$ & $\begin{array}{l}\mathbf{F 3} \\
(\%)\end{array}$ & $\begin{array}{l}\mathbf{F 4} \\
(\%)\end{array}$ & $\begin{array}{l}\mathbf{F 5} \\
(\%)\end{array}$ & $\begin{array}{l}\text { F6 } \\
(\%)\end{array}$ & $\begin{array}{l}\text { Rate of } \\
\text { extractio } \\
n(\mu \mathrm{g} / \mathrm{g})\end{array}$ & $\begin{array}{l}\text { Saturated } \\
\text { hydrocarbo } \\
\text { ns (\%) }\end{array}$ & $\begin{array}{l}\text { Aromatic } \\
\text { hydrocarbo } \\
\text { ns }(\%)\end{array}$ & $\begin{array}{l}\text { Polar } \\
\text { hydrocarbo } \\
\text { ns (\%) }\end{array}$ \\
\hline \multicolumn{18}{|c|}{ Weathering profiles } \\
\hline $\begin{array}{l}\text { A- } \\
\text { LA1V1 } \\
-1\end{array}$ & 399 & 1.87 & 178 & & & & & 0.00 & \begin{tabular}{|l|}
4.5 \\
0
\end{tabular} & \begin{tabular}{|l}
36.0 \\
0
\end{tabular} & $\begin{array}{l}17.0 \\
0\end{array}$ & \begin{tabular}{|l|}
29.0 \\
0
\end{tabular} & $\begin{array}{l}13.5 \\
0\end{array}$ & & & & \\
\hline $\begin{array}{l}\text { A- } \\
\text { LA1V1 } \\
-2\end{array}$ & 388 & 1.02 & 126 & $\begin{array}{l}1.0 \\
7\end{array}$ & $\begin{array}{l}0.0 \\
8\end{array}$ & $\begin{array}{l}13.9 \\
8\end{array}$ & $\begin{array}{l}-26.1 \\
5\end{array}$ & 0.00 & $\begin{array}{l}\text { 0.0 } \\
0\end{array}$ & \begin{tabular}{|l|}
34.0 \\
0
\end{tabular} & $\begin{array}{l}76.5 \\
0\end{array}$ & 0.00 & 5.00 & 71.30 & 8.10 & 36.10 & 55.80 \\
\hline $\begin{array}{l}\text { A- } \\
\text { LA1V1 } \\
-3\end{array}$ & 383 & 0.86 & 119 & & & & & 0.00 & $\begin{array}{l}\text { 0.0 } \\
0\end{array}$ & $\begin{array}{l}27.0 \\
0\end{array}$ & $\begin{array}{l}\text { 70.0 } \\
0\end{array}$ & 0.00 & 6.00 & & & & \\
\hline $\begin{array}{l}\text { A- } \\
\text { LA1V1 } \\
-4\end{array}$ & 371 & 0.61 & 103 & & & & & 0.00 & $\begin{array}{l}\text { 0.0 } \\
0\end{array}$ & $\begin{array}{l}20.0 \\
0\end{array}$ & \begin{tabular}{|l|}
48.0 \\
0
\end{tabular} & \begin{tabular}{|l|}
14.0 \\
0
\end{tabular} & $\begin{array}{l}18.0 \\
0\end{array}$ & & & & \\
\hline $\begin{array}{l}\text { A- } \\
\text { LA1V1 } \\
-5\end{array}$ & 336 & 0.49 & 127 & & & & & $\begin{array}{l}24.5 \\
0\end{array}$ & $\begin{array}{l}\text { 0.0 } \\
0\end{array}$ & $\begin{array}{l}44.5 \\
0\end{array}$ & 0.00 & \begin{tabular}{|l|}
24.0 \\
0
\end{tabular} & 7.00 & & & & \\
\hline $\begin{array}{l}\text { A- } \\
\text { LA1V1 } \\
-6\end{array}$ & 387 & 0.24 & 188 & $\begin{array}{l}0.4 \\
5\end{array}$ & $\begin{array}{l}0.0 \\
7\end{array}$ & 6.20 & $\begin{array}{l}-26.6 \\
4\end{array}$ & $\begin{array}{l}27.5 \\
0\end{array}$ & $\begin{array}{l}\text { 0.0 } \\
0\end{array}$ & $\begin{array}{l}41.0 \\
0\end{array}$ & 7.00 & $\begin{array}{l}12.0 \\
0\end{array}$ & $\begin{array}{l}12.5 \\
0\end{array}$ & 35.60 & 6.50 & 17.40 & 76.10 \\
\hline $\begin{array}{l}\text { A- } \\
\text { LA1V1 } \\
-7\end{array}$ & 384 & 0.28 & 82 & & & & & \begin{tabular}{|l|}
28.5 \\
0
\end{tabular} & $\begin{array}{l}\text { 0.0 } \\
0\end{array}$ & \begin{tabular}{|l|}
38.0 \\
0
\end{tabular} & 8.50 & \begin{tabular}{|l|}
15.0 \\
0
\end{tabular} & $\begin{array}{l}10.0 \\
0\end{array}$ & & & & \\
\hline $\begin{array}{l}\text { A- } \\
\text { LA1V1 } \\
-8\end{array}$ & 234 & 0.25 & 96 & $\begin{array}{l}0.3 \\
7\end{array}$ & $\begin{array}{l}0.0 \\
7\end{array}$ & 5.29 & $\begin{array}{l}-26.3 \\
6\end{array}$ & \begin{tabular}{|l|}
38.5 \\
0
\end{tabular} & $\begin{array}{l}\text { 0.0 } \\
0\end{array}$ & \begin{tabular}{|l}
34.0 \\
0
\end{tabular} & $\begin{array}{l}12.0 \\
0\end{array}$ & $\begin{array}{l}10.0 \\
0\end{array}$ & 5.50 & 53.40 & 50.60 & 23.10 & 26.30 \\
\hline $\begin{array}{l}\text { A- } \\
\text { LA1V1 } \\
-9\end{array}$ & 238 & 0.37 & 59 & & & & & $\begin{array}{l}28.0 \\
0\end{array}$ & $\begin{array}{l}\text { 0.0 } \\
0\end{array}$ & \begin{tabular}{|l}
34.5 \\
0
\end{tabular} & 8.00 & $\begin{array}{l}13.5 \\
0\end{array}$ & $\begin{array}{l}16.0 \\
0\end{array}$ & & & & \\
\hline $\begin{array}{l}\text { A- } \\
\text { LA1V1 } \\
-10\end{array}$ & 215 & 0.27 & 126 & $\begin{array}{l}0.3 \\
9\end{array}$ & $\begin{array}{l}0.0 \\
7\end{array}$ & 5.48 & $\begin{array}{l}-26.2 \\
6\end{array}$ & $\begin{array}{l}49.0 \\
0\end{array}$ & $\begin{array}{l}\text { 0.0 } \\
0\end{array}$ & $\begin{array}{l}37.0 \\
0\end{array}$ & 8.00 & 0.00 & 6.00 & 74.20 & 3.00 & 10.20 & 86.80 \\
\hline $\begin{array}{l}\text { A- } \\
\text { LAV2- } \\
1\end{array}$ & 502 & 0.26 & 8 & $\begin{array}{l}0.5 \\
3\end{array}$ & $\begin{array}{l}0.0 \\
8\end{array}$ & 6.63 & $\begin{array}{l}-28.1 \\
8\end{array}$ & & & & & & & 46.50 & 0.00 & 29.30 & 70.70 \\
\hline $\begin{array}{l}\text { A- } \\
\text { LAV2- } \\
2 \mathrm{pl}\end{array}$ & 582 & 0.71 & 7 & & & & & & & & & & & & & & \\
\hline $\begin{array}{l}\text { A- } \\
\text { LAV2- } \\
2 \mathrm{tf}\end{array}$ & 55 & 0.38 & 11 & & & & & & & & & & & 33.30 & 14.50 & 43.50 & 42.00 \\
\hline $\begin{array}{l}\text { ALAV } \\
2-3 \mathrm{pl}\end{array}$ & 608 & 0.26 & 4 & $\begin{array}{l}0.3 \\
5\end{array}$ & $\begin{array}{l}0.0 \\
6\end{array}$ & 5.71 & $\begin{array}{l}-27.7 \\
9\end{array}$ & & & & & & & & & & \\
\hline $\begin{array}{l}\text { A- } \\
\text { LAV2- } \\
3 \mathrm{tf}\end{array}$ & 499 & 0.41 & 22 & & & & & & & & & & & & & & \\
\hline $\begin{array}{l}\text { A- } \\
\text { LAV2- } \\
4\end{array}$ & 593 & 0.46 & 7 & & & & & & & & & & & 25.50 & 19.60 & 19.60 & 60.80 \\
\hline $\begin{array}{l}\text { A- } \\
\text { LAV2- } \\
5\end{array}$ & 591 & 0.07 & 0 & $\begin{array}{l}0.4 \\
2\end{array}$ & $\begin{array}{l}0.0 \\
6\end{array}$ & 7.06 & $\begin{array}{l}-28.4 \\
1\end{array}$ & & & & & & & 47.30 & 14.80 & 36.40 & 28.80 \\
\hline $\begin{array}{l}\text { A- } \\
\text { LAV2- } \\
6\end{array}$ & 589 & 0.38 & 11 & $\begin{array}{l}0.5 \\
7\end{array}$ & $\begin{array}{l}0.0 \\
6\end{array}$ & 7.04 & $\begin{array}{l}-28.1 \\
0\end{array}$ & & & & & & & 25.80 & 6.50 & 40.70 & 52.80 \\
\hline
\end{tabular}




\begin{tabular}{|c|c|c|c|c|c|c|c|c|c|c|c|c|c|c|c|c|c|}
\hline $\begin{array}{l}\text { Sampl } \\
\text { e }\end{array}$ & $\begin{array}{l}\boldsymbol{T}_{\mathrm{ma}} \\
\mathrm{x} \\
{ }^{\circ}{ }^{\circ} \mathrm{C} \\
)^{\circ}\end{array}$ & \begin{tabular}{|l} 
TO \\
C \\
$(\%)$
\end{tabular} & \begin{tabular}{|l} 
IH \\
$(\mathbf{H C}$ \\
$\mathbf{g}^{-1}$ \\
COT \\
) \\
\end{tabular} & $\begin{array}{l}\text { C } \\
(\% \\
)\end{array}$ & $\begin{array}{l}\mathbf{N} \\
(\% \\
)\end{array}$ & $\mathrm{C} / \mathrm{N}$ & $\begin{array}{l}\partial^{13} \mathbf{C} \\
(\%)\end{array}$ & $\begin{array}{l}\mathrm{F} 1 \\
(\%)\end{array}$ & $\begin{array}{l}\mathbf{F 2} \\
(\% \\
)\end{array}$ & $\begin{array}{l}\mathbf{F 3} \\
(\%)\end{array}$ & $\begin{array}{l}\mathrm{F} 4 \\
(\%)\end{array}$ & $\begin{array}{l}\text { F5 } \\
(\%)\end{array}$ & $\begin{array}{l}\text { F6 } \\
(\%)\end{array}$ & $\begin{array}{l}\text { Rate of } \\
\text { extractio } \\
n(\mu \mathrm{g} / \mathrm{g})\end{array}$ & $\begin{array}{l}\text { Saturated } \\
\text { hydrocarbo } \\
\text { ns (\%) }\end{array}$ & $\begin{array}{l}\text { Aromatic } \\
\text { hydrocarbo } \\
\text { ns (\%) }\end{array}$ & $\begin{array}{l}\text { Polar } \\
\text { hydrocarbo } \\
\text { ns (\%) }\end{array}$ \\
\hline $\begin{array}{l}\text { A- } \\
\text { LAV3- } \\
1\end{array}$ & 599 & 0.23 & 0 & $\begin{array}{l}0.5 \\
0\end{array}$ & $\begin{array}{l}0.0 \\
8\end{array}$ & 6.54 & $\begin{array}{l}-27.5 \\
5\end{array}$ & & & & & & & 32.50 & 23.10 & 30.80 & 46.10 \\
\hline $\begin{array}{l}\text { A- } \\
\text { LAV3- } \\
2\end{array}$ & 606 & 0.39 & 10 & $\begin{array}{l}0.4 \\
6\end{array}$ & $\begin{array}{l}0.0 \\
8\end{array}$ & 4.76 & $\begin{array}{l}-27.3 \\
7\end{array}$ & & & & & & & 40.60 & 14.40 & 22.50 & 63.10 \\
\hline $\begin{array}{l}\text { A- } \\
\text { LAV3- } \\
3\end{array}$ & 604 & 0.42 & 7 & $\begin{array}{l}0.5 \\
2\end{array}$ & $\begin{array}{l}0.0 \\
8\end{array}$ & 6.60 & $\begin{array}{l}-27.5 \\
1\end{array}$ & & & & & & & & & & \\
\hline $\begin{array}{l}\text { A- } \\
\text { LAV3- } \\
4\end{array}$ & 599 & 0.45 & 7 & & & & & & & & & & & 57.20 & 29.60 & 35.20 & 35.20 \\
\hline $\begin{array}{l}\text { A- } \\
\text { LAV3- } \\
5\end{array}$ & 574 & 0.49 & 24 & $\begin{array}{l}0.5 \\
5\end{array}$ & $\begin{array}{l}0.7 \\
0\end{array}$ & 7.31 & $\begin{array}{l}-27.7 \\
0\end{array}$ & & & & & & & & & & \\
\hline $\begin{array}{l}\text { A- } \\
\text { LAV3- } \\
6\end{array}$ & 598 & 0.43 & 19 & & & & & & & & & & & 35.60 & 25.60 & 37.80 & 36.60 \\
\hline $\begin{array}{l}\text { A- } \\
\text { LAV3- } \\
7\end{array}$ & 602 & 0.43 & 7 & & & & & & & & & & & & & & \\
\hline $\begin{array}{l}\text { A- } \\
\text { BRUV } \\
1-2\end{array}$ & 378 & 2.39 & 133 & $\begin{array}{l}0.5 \\
0\end{array}$ & $\begin{array}{l}0.7 \\
0\end{array}$ & 7.40 & $\begin{array}{l}-27.8 \\
3\end{array}$ & & & & & & & 65.30 & 11.70 & 24.00 & 64.30 \\
\hline $\begin{array}{l}\text { A- } \\
\text { BRUV } \\
1-3 \mathrm{pl}\end{array}$ & 178 & 0.06 & 0 & & & & & & & & & & & & & & \\
\hline $\begin{array}{l}\text { A- } \\
\text { BRUV } \\
1-3 \mathrm{tf}\end{array}$ & 407 & 2.00 & 129 & & & & & & & & & & & & & & \\
\hline $\begin{array}{l}\text { A- } \\
\text { BRUV } \\
1-4\end{array}$ & 338 & 0.89 & 82 & & & & & & & & & & & & & & \\
\hline $\begin{array}{l}\text { A- } \\
\text { BRUV } \\
1-5\end{array}$ & 348 & 0.88 & 83 & & & & & & & & & & & & & & \\
\hline $\begin{array}{l}\text { A- } \\
\text { BRUV } \\
1-6 \mathrm{pl}\end{array}$ & 263 & 0.12 & 0 & $\begin{array}{l}0.2 \\
4\end{array}$ & $\begin{array}{l}0.0 \\
5\end{array}$ & 5.00 & $\begin{array}{l}-27.0 \\
5\end{array}$ & & & & & & & 60.90 & 4.30 & 50.80 & 44.90 \\
\hline $\begin{array}{l}\text { A- } \\
\text { BRUV } \\
1-6 \mathrm{tf}\end{array}$ & 333 & 0.76 & 96 & $\begin{array}{l}0.6 \\
7\end{array}$ & $\begin{array}{l}0.1 \\
0\end{array}$ & 7.10 & $\begin{array}{l}-26.1 \\
7\end{array}$ & & & & & & & 50.10 & 4.10 & 74.80 & 21.10 \\
\hline $\begin{array}{l}\text { A- } \\
\text { BRUV } \\
1-7\end{array}$ & 592 & 0.09 & 0 & & & & & & & & & & & & & & \\
\hline $\begin{array}{l}\text { A- } \\
\text { BRUV } \\
1-8\end{array}$ & 250 & 0.15 & 0 & $\begin{array}{l}0.2 \\
8\end{array}$ & $\begin{array}{l}0.0 \\
4\end{array}$ & 6.30 & $\begin{array}{l}-26.9 \\
5\end{array}$ & & & & & & & 30.00 & 10.10 & 51.70 & 38.20 \\
\hline $\begin{array}{l}\text { A- } \\
\text { BRV2- } \\
1\end{array}$ & 374 & 6.03 & 492 & & & & & & & & & & & & & & \\
\hline $\begin{array}{l}\text { A- } \\
\text { BRV2- } \\
2\end{array}$ & 336 & $\begin{array}{l}17.7 \\
1\end{array}$ & 336 & & & & & & & & & & & & & & \\
\hline $\begin{array}{l}\text { A- } \\
\text { BRV2- } \\
3 \mathrm{pl}\end{array}$ & 502 & 0.36 & 6 & & & & & & & & & & & & & & \\
\hline $\begin{array}{l}\text { A- } \\
\text { BRV2- } \\
3 \mathrm{tf}\end{array}$ & 323 & 3.81 & 261 & $\begin{array}{l}3.9 \\
4\end{array}$ & $\begin{array}{l}0.2 \\
5\end{array}$ & $\begin{array}{l}16.0 \\
0\end{array}$ & $\begin{array}{l}-25.3 \\
4\end{array}$ & & & & & & & 1051.60 & 4.40 & 6.90 & 88.70 \\
\hline
\end{tabular}




\begin{tabular}{|c|c|c|c|c|c|c|c|c|c|c|c|c|c|c|c|c|c|}
\hline $\begin{array}{l}\text { Sampl } \\
\text { e }\end{array}$ & $\begin{array}{l}T_{\text {ma }} \\
\text { x } \\
\left({ }^{\circ} \mathrm{C}\right. \\
)\end{array}$ & $\begin{array}{l}\text { TO } \\
\text { C } \\
(\%)\end{array}$ & \begin{tabular}{|l}
$\mathbf{I H}$ \\
$(\mathbf{H C}$ \\
$\mathbf{g}^{-1}$ \\
$\mathbf{C O T}$ \\
)
\end{tabular} & $\begin{array}{l}\text { C } \\
(\% \\
)\end{array}$ & $\begin{array}{l}\mathbf{N} \\
(\% \\
)\end{array}$ & C/N & $\begin{array}{l}\partial^{13} \mathrm{C} \\
(\%)\end{array}$ & $\begin{array}{l}\text { F1 } \\
(\%)\end{array}$ & $\begin{array}{l}\text { F2 } \\
(\%) \\
)\end{array}$ & $\begin{array}{l}\text { F3 } \\
(\%)\end{array}$ & $\begin{array}{l}F 4 \\
(\%)\end{array}$ & $\begin{array}{l}\text { F5 } \\
(\%)\end{array}$ & $\begin{array}{l}\text { F6 } \\
(\%)\end{array}$ & $\begin{array}{l}\text { Rate of } \\
\text { extractio } \\
n(\mu \mathrm{g} / \mathrm{g})\end{array}$ & $\begin{array}{l}\text { Saturated } \\
\text { hydrocarbo } \\
\text { ns (\%) }\end{array}$ & $\begin{array}{l}\text { Aromatic } \\
\text { hydrocarbo } \\
\text { ns (\%) }\end{array}$ & $\begin{array}{l}\text { Polar } \\
\text { hydrocarbo } \\
\text { ns (\%) }\end{array}$ \\
\hline $\begin{array}{l}\text { A- } \\
\text { BRV2- } \\
4 \mathrm{pl}\end{array}$ & 509 & 0.29 & 0 & $\begin{array}{l}0.4 \\
5\end{array}$ & $\begin{array}{l}0.0 \\
6\end{array}$ & 7.90 & $\begin{array}{l}-25.2 \\
1\end{array}$ & & & & & & & 447.40 & 0.40 & 0.50 & 99.10 \\
\hline $\begin{array}{l}\text { A- } \\
\text { BRV2- } \\
4 \text { tf }\end{array}$ & 415 & 3.25 & 223 & $\begin{array}{l}0.9 \\
9\end{array}$ & $\begin{array}{l}0.0 \\
8\end{array}$ & $\begin{array}{l}12.1 \\
0\end{array}$ & $\begin{array}{l}-25.1 \\
5\end{array}$ & & & & & & & 814.00 & 2.40 & 8.30 & 89.30 \\
\hline $\begin{array}{l}\text { A- } \\
\text { BRV2- } \\
5 \mathrm{pl}\end{array}$ & 481 & 0.22 & 0 & $\begin{array}{l}0.4 \\
3\end{array}$ & $\begin{array}{l}0.0 \\
5\end{array}$ & 7.90 & $\begin{array}{l}-25.0 \\
1\end{array}$ & & & & & & & 517.00 & 3.70 & 4.90 & 91.40 \\
\hline $\begin{array}{l}\text { A- } \\
\text { BRV2- } \\
5 \text { tf }\end{array}$ & 418 & 2.55 & 171 & & & & & & & & & & & & & & \\
\hline
\end{tabular}




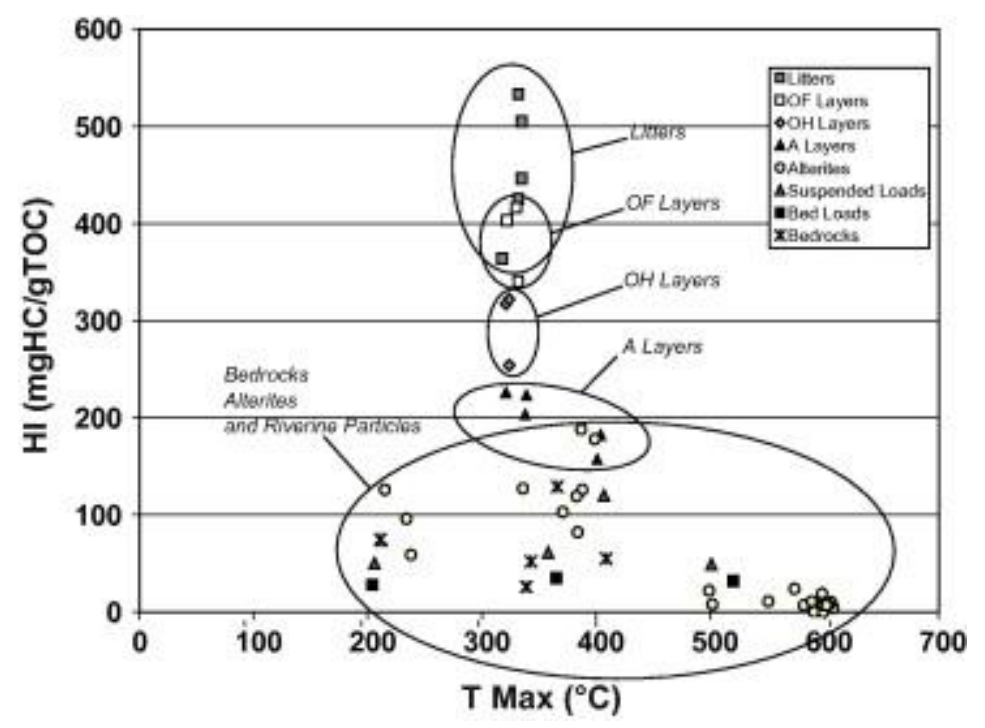

Fig. 3. : HI vs. $T_{\max }$ values of the samples. OL: litter layers; OF: fragmentation layers; $O H$ : humic layers; A: organo-mineral layers.

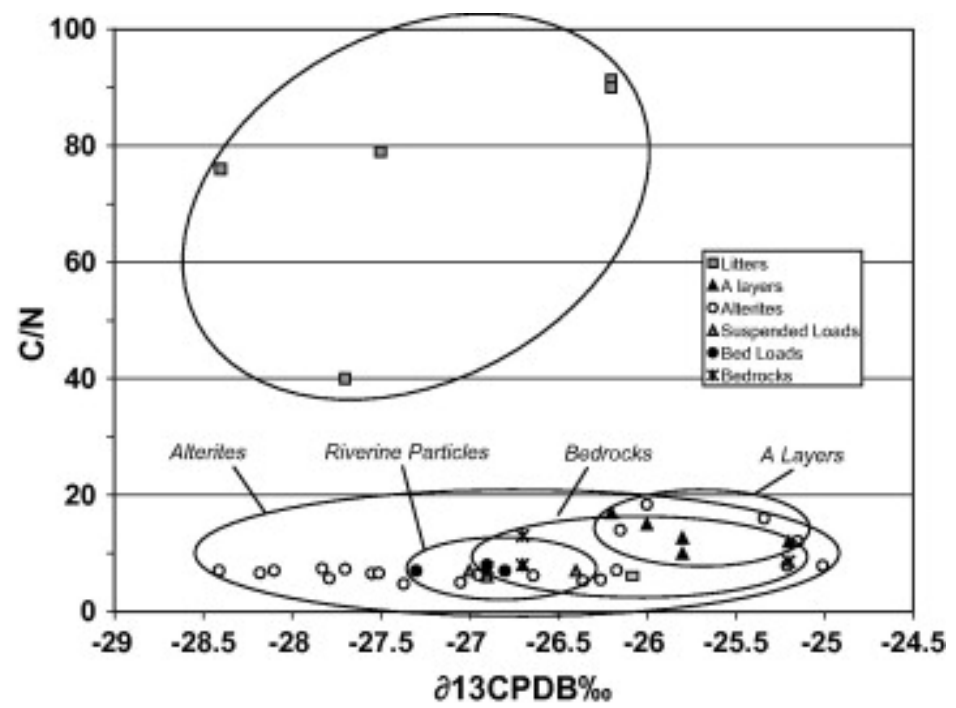

Fig. 4. :C/N vs. $\delta^{13}$ values of the samples. OL: litter layers; OF: fragmentation layers; $O H$ : humic layers; A: organo-mineral layers. 

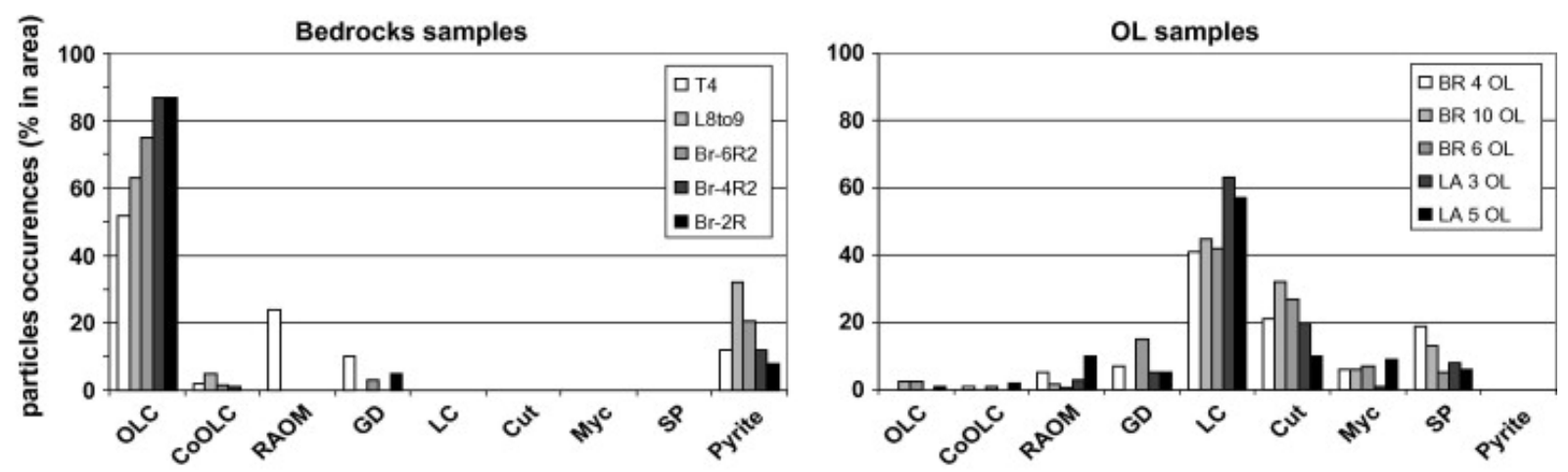

Fig. 5. : Palynofacies counting of bedrock and OL (litter) samples.
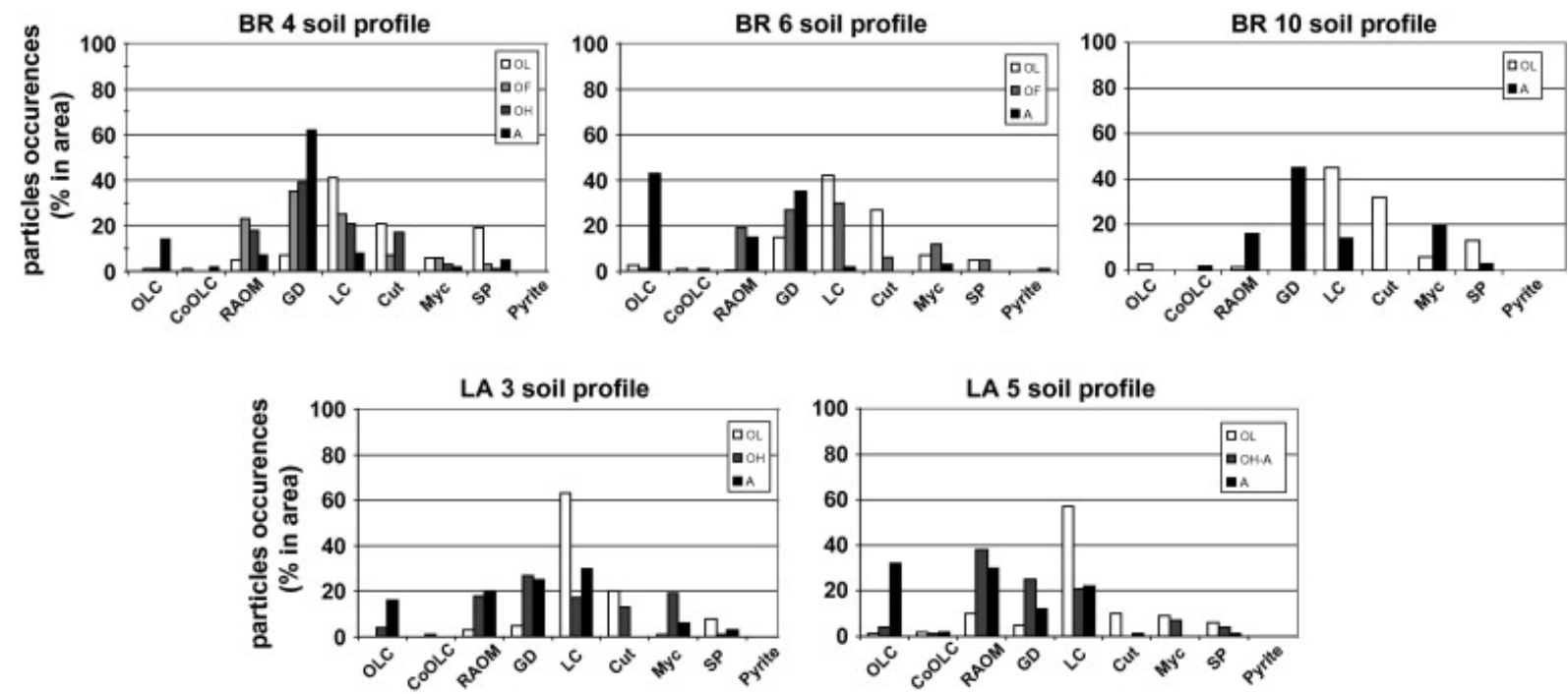

Fig. 6. :Palynofacies counting of soil profiles. OL: litter layers; OF: fragmentation layers; OH: humic layers; A: organo-mineral layers. 

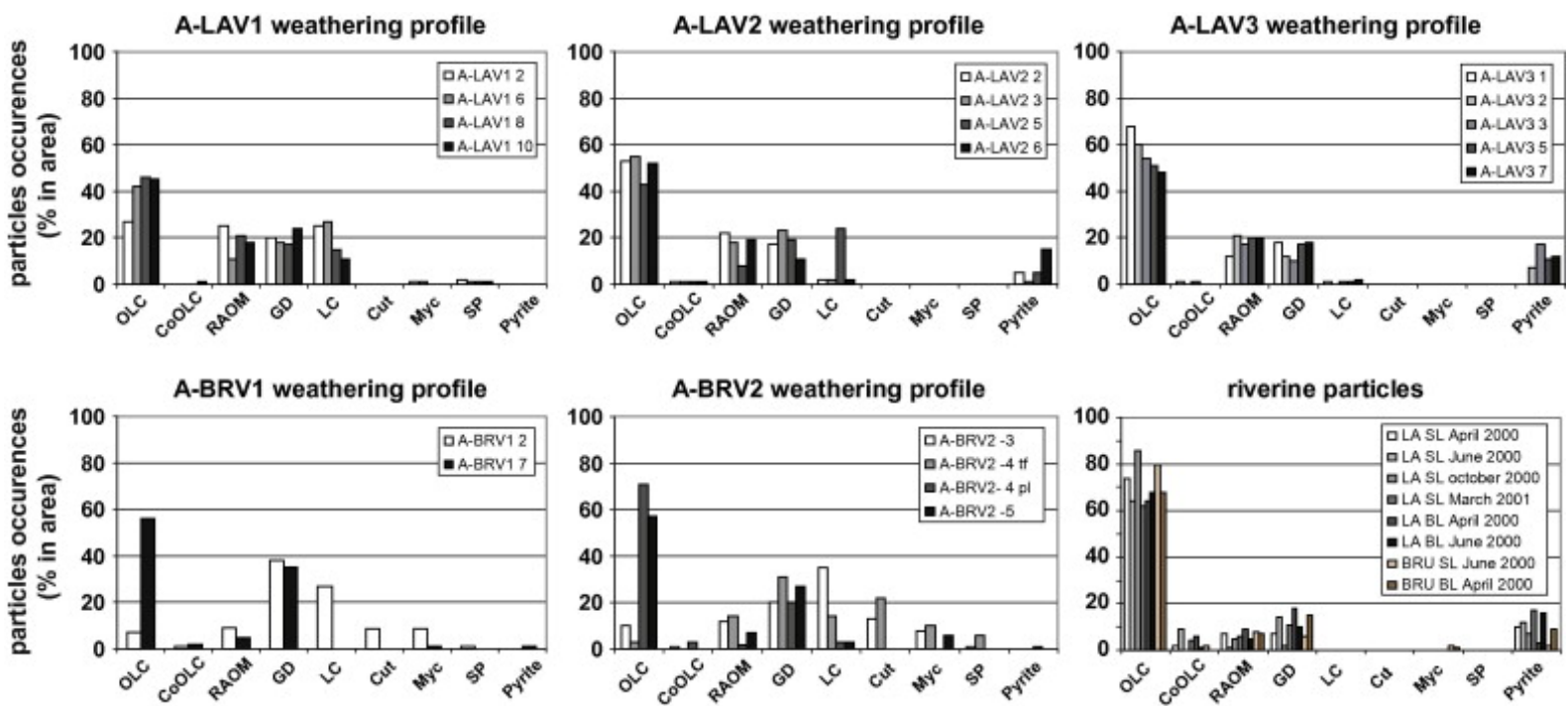

Fig. 7. : Palynofacies counting of weathering profiles and riverine particle samples. $p l$ : compact fragments of rock samples; $t$ : fine and friable elements.

(a) A-BRV1 weathering profile

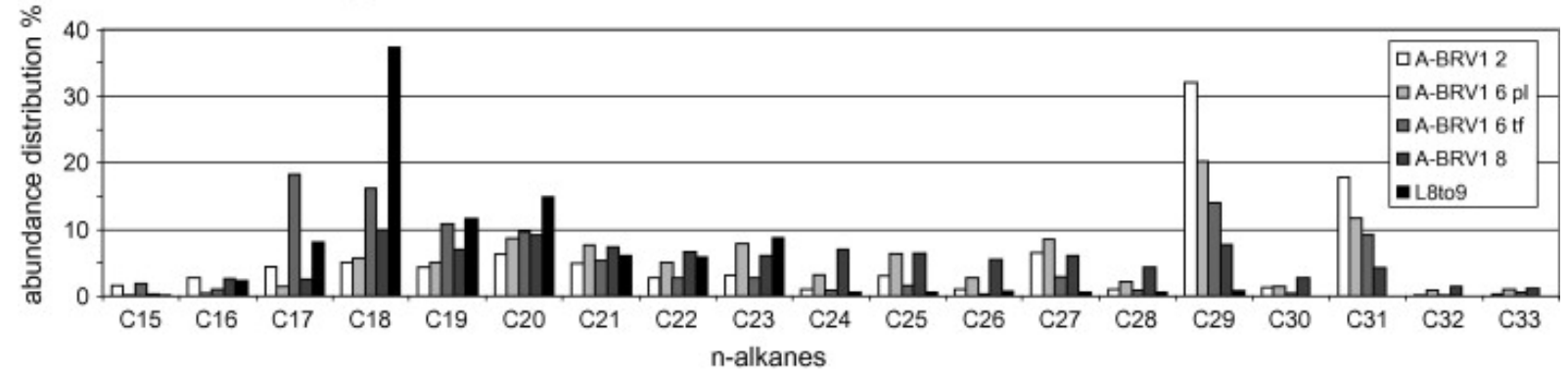

(b) A-BRV2 weathering profile

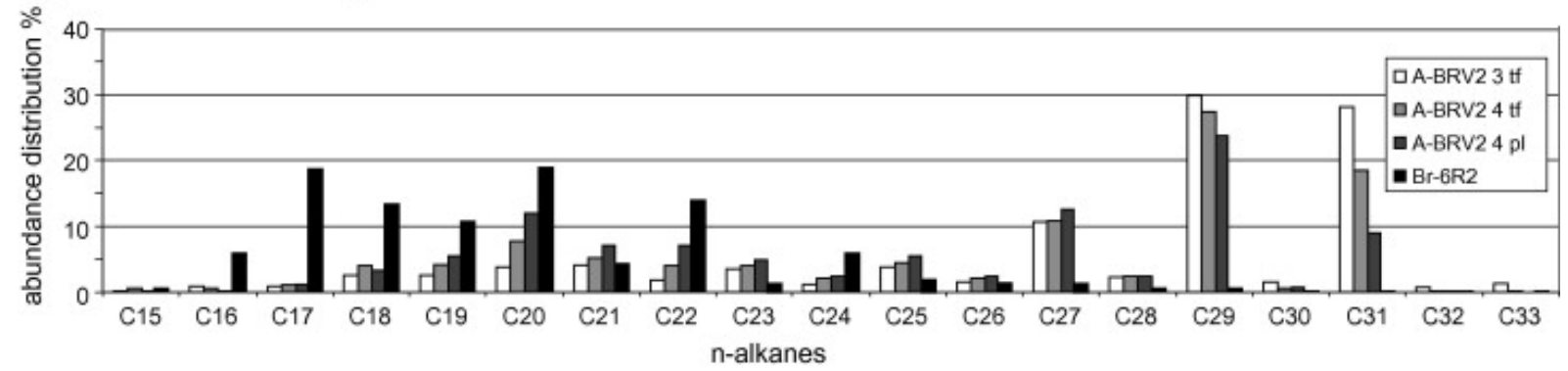

Fig. 8. : n-Alkane abundance distribution (\%) after pic areas integration and normalisation. (a) A-BRV1 samples and L8TO9 Toarcian bedrock sample; (b) A-BRV2 samples and Br-6R2 upper-Aalenian bedrock sample. pl: compact fragments of rock samples; $t f$ : fine and friable elements. 
